\title{
AUNC
}

Zabytkoznawstwo i Konserwatorstwo XLVII

Toruń 2016

DOI: http://dx.doi.org/10.12775/AUNC_ZiK.2016.004

\section{Uwagi o fikcji i fantazji w nowożytnej symbolice zwierząt}

\section{ALICJA SAAR-KOZŁOWSKA}

Zakład Muzealnictwa, Wydział Sztuk Pięknych, UMK w Toruniu

e-mail: alicja-saar@o2.pl

Keywords: animal symbolism, fiction and fantasy in symbolism, Renaissance hieroglyphs, emblematics, iconological personifications

Słowa kluczowe: symbolika zwierzęca, fikcja i fantazja w symbolice, hieroglify okresu renesansu, emblematyka, personifikacje ikonologiczne

\begin{abstract}
Remarks on fiction and fantasy in the Early Modern animal symbolism

In works concerning animals fiction and fantasy have marked their constant presence from the past till the present. From these perennial themes new senses and projections stem that tap freely into the reservoir of the former times. Thanks to the state of art methods and means of forming an image erstwhile fictions assume some "real" shape in virtual art. Over the centuries the phenomenon of repossessing tradition of image creation and symbolization lead to the formation in the $15^{\text {th }}, 16^{\text {th }}$ and $17^{\text {th }}$ centuries of a new symbolic code. Therein as a result of fascination with the manuscript by Horapollo's Hieroglyphica discovered in 1419, believed to be an Egyptian original, in fact an Alexandrian work dating from the 5th century A. C., the old symbolism, although compiled and supplanted with new ideas, was preserved and extended in the form of the Renaissance hieroglyphs (not identical with the Egyptian ones). Not only does this article attempt to consider modern animal symbolism, but also to investigate the issue of repossessing the attainments of the predecessors by artists whose output contributed significantly to forging this tradition, namely Andrea Alciato, considered to be the originator of emblematics, the author of Emble-
\end{abstract}


matum liber (1531), Pierio Valeriano the author of Hieroglyphica, the compendium of symbols (1556), Cesare Ripa the author of Iconology (1593, illustrated edition 1603). Horapollo's manuscript (published in Greek in 1505 and Latin in 1517) contributed to elevating the rank of works combining picture with a verbal commentary and inspired with this idea modern authors. Extensive symbolic motives in the works of Valeriano to a significant degree provided a prescription for presenting abstract concepts by Ripa, along with Vincenzo Cartari (not mentioned in Ripa`s book), Alciati, Horapollo and a whole cohort of ancient authors. Nowadays new mythologies relating to literary, cinematographic works and computer games have come into being. They take advantage of age-old symbolic codes and create new ones. These works do deserve the privilege to be examined since they are yet another manifestation of preserving the tradition of animal symbolism.

\begin{abstract}
Abstrakt
W dziełach dotyczących zwierząt fikcja i fantazja mają swój nieskończony żywot od czasów najdawniejszych po współczesne. Na bazie odwiecznych treści kreowane są sensy i wyobrażenia nowe swobodnie czerpiące z dorobku poprzednich epok. Dzięki nowoczesnym metodom i środkom kształtowania obrazu niegdysiejsze fikcje przybierają w sztuce wirtualnej „realny” kształt. Na przestrzeni wieków zjawisko przejmowania tradycji obrazowania i symbolizowania doprowadziło do powstania w wiekach XV-XVII nowego kodu symbolicznego, w którym dzięki fascynacji odkrytym w 1419 r. manuskryptem Hieroglifów Horapollona, traktowanym jako egipski oryginał, w rzeczywistości dzieło aleksandryjskie z $\mathrm{V}$ w. n.e., zachowano i rozbudowano w postaci hieroglifów okresu renesansu (nie tożsamych z egipskimi), konstrukcji słowno-obrazowych (emblematów) oraz personifikacji ikonologicznych dawną symbolikę kompilując ją oraz dodając treści nowe. Artykuł jest próbą rozważań nie tylko nad charakterem nowożytnej symboliki zwierzęcej, ale także prześledzenia mechanizmu przejmowania dorobku poprzedników w tym zakresie przez twórców, których dorobek jest istotny dla jej kształtowania - Andreę Alciatiego, uznawanego za twórcę emblematyki, autora Emblematum liber (1531), Pieria Valeriano autora kompendium symbolograficznego Hieroglifika (1556), Cesarego Ripy autora Iconologii (1593, wyd. ilustrowane 1603). Manuskrypt Horapollona (wyd. w języku greckim 1505, łacińskim 1517) wpłynął na podniesienie rangi wypowiedzi łączących obraz ze słownym komentarzem i zainspirował w tym kierunku autorów nowożytnych. Rozbudowane motywy symboliczne w pracy Valeriana stały się w dużej mierze podstawą przepisów na obrazowanie pojęć abstrakcyjnych Ripy, obok Vincenzo Cartariego (nie wymienionego w pracy), Alciatiego, Horapollona i całej rzeszy autorów antycznych oraz autorytetu Pisma Świętego. Obecnie powstają nowe mitologie związane z dziełami literackimi, filmowymi oraz grami komputerowymi, posługujące się symboliką dawną i tworzące nową, które także zasługują na zbadanie jako przejaw korzystania z dorobku tradycji symboliki m.in. zwierzęcej.
\end{abstract}


Znaczący wpływ na upowszechnienie w czasach nowożytnych pełnej fantazji i fikcji symboliki zwierzęcej, znanej od antyku, miało powstanie i rozwój w XVI wieku emblematyki i ikonologii ${ }^{1}$. Sięgały one do najdawniejszych przekazów, propagowały je i utrwalały, wspierały też dążenia do stworzenia wspólnego języka sztuki - ustalonego, systematycznego katalogu symboli, hieroglifów ${ }^{2}$, emblematów ${ }^{3}$, ikonologicznych personifikacji, traktowanych

1 O tworzeniu nowożytnych wypowiedzi o charakterze symbolicznym (hieroglify okresu renesansu, emblematy, personifikacje ikonologiczne) oraz roli w tym procesie Hieroglifów Horapollona zob. Alicja Saar-Kozłowska, „Potrzeba fikcji i fantazji. Uwagi o symbolice zwierzęcej”, w Kolekcja fikcji. O mistyfikacji w sztuce, red. Małgorzata Wawrzak (Toruń: Wydawnictwo Naukowe UMK, 2016), 91-118 (tam podana literatura przedmiotu). Zob. też m.in. Teresa Michałowska, Staropolska teoria genologiczna (Wrocław: Ossolineum; Warszawa: PAN, 1974); Jadwiga Bednarska, $Z$ dziejów polskiej ilustracji panegirycznej pierwszej połowy XVII wieku, cz. 1 Motywy i tematy antyczne w polskiej panegirycznej ilustracji książkowej. Studium z ikonografii sztuki nowożytnej (Katowice: Muzeum Śląskie, 1994), 31. Z literatury poświęconej symbolice zwierząt zob. m.in. Beryl Rowland, Animals with Human Souls: A Guide to Animal Symbolism (Knoxville: University of Tennessee Press, 1973), XVIII-XIX (źródła i literatura, m.in. prace Pliniusza, Eliana, anonimowego autora Fizjologa, Horapollona, Conrada Gesnera, Historia animalium, Zurich: C. Forschauer, 1551-1558, Pratologia Graeca); Zofia Drapela, Od Lewiatana do Jormungandra: rzecz o potworach morskich, ludziach z morza i duchach wód, ilustr. Tadeusz Ciesiulewicz (Gdańsk: Wydawnictwo Morskie, 1976); Beryl Rowland, Birds with Human Souls: A Guide to Bird Symbolism (Knoxville: University of Tennessee Press, 1978); Jean-Paul Ronecker, Le symbolisme animal: Mythes, croyances, légendes, archétypes, folklore, imaginaire... (St.-Jean-de-Braye: Editions Dangles, 1994), 327-331 (bibliografia); Jean C. Cooper, Zwierzęta symboliczne i mityczne, tłum. Anna Kozłowska-Ryś, Leszek Ryś (Poznań: Rebis, 1998); Stanisław Kobielus, Bestiarium chrześcijańskie. Zwierzęta w symbolice i interpretacji. Starożytność i średniowiecze (Warszawa: PAX, 2002), 411-430 (wykaz źródeł i opracowań).

2 Rudolf Wittkower, "Hieroglyphics in the Early Renaissance", w Rudolf Wittkower, Allegory and the Migration of Symbols (New York: Thames and Hudson, 1987), 114-128, m.in. 114 przypis 2 (211): literatura dotycząca badań nad Hieroglifikq Horapollona, hieroglifiką i emblematyką renesansową; Jacek Sokolski, „Wstęp”, w Horapollon, Hieroglify, tłum. i komentarz Jerzy Kroczek, wstęp Jacek Sokolski (Wrocław: Wydawnictwo UWr, 2003), bogata literatura do tematu; Luc Brisson, How Philosophers Save Myths. Allegorical Interpretation and Classical Mythology (Chicago: University of Chicago Press, 2004), 141 (dostęp 20 sierpnia). 2015,http:// eds.b.ebscohost.com/eds/ebookviewer/ebook/ZTAwMHh3d19fMjYwMTA2X19BTg2?sid=ca941352-d3b5-4a07-bc3f-3163f0edd041@sessionmgr113\&vid=0\&format=EB \&rid=1; Anna Klimkiewicz, Hypnerotomachia Poliphili Francesca Colonny (Kraków: Wydawnictwo UJ, 2015); Hypnerotomachia Poliphili, http://www.rarebookroom.org/Control/colhyp/index.html (dostęp 20 lipca 2015).

3 William S. Heckscher i Karl-August Wirth, „Emblem - Emblembuch“, w Reallexikon zur deutschen Kunstgeschichte, t. 5, z. 49 (Stuttgart: Alfred Druckenmüller, 1959), 85-228; Janusz Pelc, Słowo i obraz. Na pograniczu literatury i sztuk plastycznych (Kraków: Universitas, 2002); Andrea Alciatus, Emblematum libellus. Książeczka emblematów, tłum. i komentarze pod kier. Mieczysława Mejora: Anna Dawidziuk, Bianka Dziadkiewicz i Ewa Kustroń-Zaniewska, wstęp i oprac. Roman Krzywy (Warszawa: Wydział Polonistyki UW, 2002). 
jako znaki umowne. Ich zadaniem - tak jak symboli plastycznych - było wyrażanie ukrytych treści. Towarzyszyć im miały zespoły odpowiednio dobranych słów określających symbolikę4. Proces konstruowania form wypowiedzi o symbolicznym charakterze, ich przekształcania i kompilowania, toczył się przez wieki i trwa do dziś.

Od najdawniejszych czasów fikcja i fantazja mają w dziełach dotyczących zwierząt lub tylko wykorzystujących ich motyw stałe miejsce. Współcześnie z ogromnym zainteresowaniem sięga się do prastarych wyobrażeń, „miksuje” je i dzięki nowym środkom obrazowania nadaje bardziej „realny” i często synkretyczny kształt. To, co było opisywane, ale nigdy niewidziane (np. smoki, jednorożce, feniks), obecnie może łatwo zaistnieć: umożliwiają to elektroniczne programy graficzne, techniki animacyjne, różnorodne tricki, makiety, praca w 3D itp. Wciąż też powstają nowe treści o charakterze fikcyjnym, ale i zarazem symbolicznym. Istnieje zatem, obok naukowej wiedzy o gatunkach, zwierzęca fikcja i fantazja, kreowana przed wiekami oraz współcześnie. Obecnie jednak zainteresowani podchodzą do niej inaczej niż niegdyś - ze świadomą i całkowitą zgodą na nierealność. Pozostaje otwarte pytanie, w którym momencie fikcja i fantazja stały się fikcją i fantazją sensu stricte? Kiedy przeszły w ludzkiej świadomości metamorfozę od niewiedzy do świadomie akceptowanej fantazji i co sprawia, że ta fantazja trwa w świecie ludzkich wyobrażeń - w sztuce, literaturze, bajkach, przysłowiach itp.? Dziś sztuka kreowania obrazu może urzeczywistnić w świecie wirtualnym każdą wcześniejszą fantazję; co więcej, z upodobaniem po nią sięga, czego dowodzą choćby filmy fantasy i gry komputerowe ${ }^{5}$.

W kulturze minionych wieków przejmowane przez człowieka umiejętności, moce oraz części ciała zwierząt użyczały lub nadawały mu ich siłę i sprawność. Obecnie w sztuce słowa i obrazu nadal obok hybryd zwierzęcych ${ }^{6}$ występują hybrydy zwierzęco-ludzkie. Pojawiają się jednak także hybrydy humanoidalno-cybernetyczne, które zresztą już dawno przekroczyły granice ścisłego świata fikcji, świadcząc o zapowiadanej przyszłości, a w pewnym stopniu również o teraźniejszości, gdy np. chodzi o wzbogacenie, rozwinięcie

4 Pelc, Słowo i obraz, 353.

5 Zob. np. o florze, faunie, istotach i rasach Śródziemia i Nieśmiertelnych Krain Johna R. R. Tolkiena - David Day i Ian Miller (ilustracje), Bestiariusz tolkienowski, tłum. Renata Giedrojć, Joanna Kokot i Jakub Z. Lichański (Poznań: Zysk i S-ka, 2001).

6 Monika Bakke, „Wyobrażone ciałem się staje. O hybrydach, monstrach i istotach postludzkich”, w O wyobraźni, red. Ryszard Liberkowski i Włodzimierz Wilowski, (Poznań: Wydawnictwo Naukowe Instytutu Filozofii UAM, 2003), 23-24. 
bądź ulepszenie funkcji ludzkiego organizmu przez wytwory techniki albo zastępowanie nimi utraconych części ludzkiego ciała.

Próbując odpowiedzieć na postawione wyżej pytania, warto przyjrzeć się niektórym źródłom istotnym dla powstawania i utrwalania wyobrażeń zwierząt oraz zwierzęcej symboliki; prześledzić mechanizmy przejmowania dorobku poprzedników przez twórców, dzięki którym zwierzęca symbolika przetrwała po współczesność, mimo rozwoju badań naukowych dyskredytujących jej wartość poznawczą i stopniowo tworzących wiedzę pozbawioną elementów fantastycznych i symbolicznych.

Przykładem długotrwałości fantastycznych idei i wyobrażeń może być Historia naturalis (1650-1653), dzieło polskiego przyrodoznawcy, historyka, filozofa, pedagoga i lekarza Jana Jonstona (1603-1675), którego prace dowodzą, że w XVII wieku przyrodoznawstwo stopniowo znalazło własny sposób opisania świata. We wspomnianej księdze, obok informacji przeselekcjonowanych w stosunku do dawniejszych prac, przedstawione zostały także np. niezwykłe ptaki znane z wcześniejszych kompendiów o charakterze symbolograficznym (np. Pierio Valeriano, Hieroglyphica, pierwsze wydanie: Basileae $1556^{7}$ ), takie jak pelikan, feniks, harpia oraz gryf ${ }^{8}$ (il. 1-4), spośród roślin zaś baranek scytyjski ${ }^{9}$, będący na granicy flory i fauny, wyrastający na szczycie łodygi i pasący się okolicznymi roślinami póki starczy mu tej karmy ${ }^{10}$ (il. 5-6). Jacek Sokolski akcentował, że „dzieła barokowych symbolografów są pełne [...] faktów wydobytych z prac Pliniusza, Eliana, Solinusa czy też średniowiecznych uczonych, jak Albert Wielki, Wincenty z Beauvais i Petrus

7 Joannis Pierio Valeriano, Hieroglyphica sive de sacris Aegyptiorum Aliarvmquae Gentium Literis (Coloniae Agrippinae: sumptibus Antonij \& Arnold Hierati, 1631), 239-241 (pelikan), 237-239 (feniks).

8 Johannes Jonstonus, Historia Naturalis de Avibus Libri VI (Francofurti ad Moenum: impensà Matthaei Meriani, 1650), tab. 62.

9 Jacek Sokolski, „Barokowa 'Physica curiosa' i koncepty księgi natury”, w Koncept w kulturze staropolskiej, red. Ludwik Ślęk, Adam Karpiński i Wiesław Pawlak (Lublin: Towarzystwo Naukowe KUL, 2005), 297.

10 John Jonston, Historiae Naturalis de Arboribus et Plantis Libri X, t. 2 (Heilbronn: F. J. Eckebrecht, 1769), tab. CXXXIV. Zob. też np. Conrad Gesner, Historia animalium (Zurich: C. Forschauer, 1551-1558); William B. Ashworth Jr, „Emblematic Natural History of the Renaissance”, w Cultures of Natural History, red. Nicholas Jardine, James A. Secord i Emma C. Spary (Cambridge: University Press, 1996), 17-3, https://books.google.pl/books?id=z9_Z9UbUIeQC\&printsec=frontcover \&hl=pl\#v=onepage \&q\&f=false; http://www.gbv.de/dms/bs/ toc/187414327.pdf; http://www.academia.edu/5359347/Cultures_of_Natural_History (dostęp 7.11.2016); Sachiko Kusukawa, "The Sources of the Gesner`s Pictures for the "Historia animalium' ", Annales of Science 67 (2010) 3: 303-328, http://www.rhinoresourcecenter. com/pdf_files/128/1286404337.pdf (dostęp 7 listopada 2016). 
Berchorius. [...] nie wszystkim tym informacjom siedemnastowieczni pisarze ufają w równym stopniu, dobrze jednak zdając sobie sprawę z faktu, iż aby stać się symbolem, dane zwierzę, roślina czy kamień nie musi wcale istnieć w rzeczywistości (wystarczy, że zaistnieje w wyobraźni ludzi), nie decydują się na ich wyeliminowanie" ${ }^{11}$.

Wiadomo, że już Arystoteles w IV wieku p.n.e., inaczej niż Platon, przyznawał sztukom oddzielną sferę działania. Prawda artystyczna była odrębna od prawdy naukowej. Wypowiedzi artystyczne były poza prawdą i poza fałszem ${ }^{12}$. Fantastyczne kształty i moce zwierząt oraz bliskość fauny, ludzi i bogów utrwalały także kulty religijne. W świecie judeochrześcijańskim hybrydyczność jako zasada pochodzi z Biblii (np. Tetramorfy, Ez 1,10; Cztery istoty żyjące, Ap 4). Zamiłowanie do fantazji i fikcji zachowało się również w ludowych wierzeniach wyrosłych z pogańskich mitów, przekształconych w baśnie i podania, o czym świadczą swoiste bestiariusze charakterystyczne dla poszczególnych kultur i regionów ${ }^{13}$. Hybrydyczność nie zanikła w czasach średniowiecza, kiedy klasyczna mitologia dotycząca zwierząt została poddana chrystianizacji, a symboliczne znaczenie danego zwierzęcia było bardziej istotne niż zgodność z rzeczywistym wyglądem lub też w ogóle jego istnienie ${ }^{14}$. Tradycję antyku i średniowiecza w zakresie literatury, filozofii i obrazowania kształtów i symboli zwierzęcych odziedziczyły czasy nowożytne i zmodyfikowały kod przekazu oraz wprowadziły nowe treści.

Źródła fantastycznej symboliki zwierzęcej, potrzebę „odnowienia” jej przez sięgnięcie do prastarej kultury egipskiej, jej trwanie obok osiągnięć nauki można prześledzić na podstawie dzieł najistotniejszych dla procesu kształtowania się nowożytnej symboliki zwierząt. Są wśród nich: Fizjolog (II-III w.), bestiaria (XII-XVII w.), Hieroglify Horapollona (V w.), Emblematum liber Andrei Alciatiego (pierwsze wydanie: Augsburg 1531), Hieroglyphica Valerianiego (pierwsze wydanie: Basilea 1556), Iconologia Cesarego Ripy (pierwsze wydanie: Roma 1593, pierwsze wydanie ilustrowane: Roma 1603) oraz Mundus symbolicus Picinellego (Coloniae Agrippinae 1687; pierwsze wydanie: Mondo Symbolico, Milano 1653). Dzieła te dzięki poczytności oraz

11 Sokolski, „Barokowa 'Physica curiosa’”, 294-295.

12 Myśliciele, kronikarze i artyści o sztuce od starożytności do 1500, wybrał i oprac. Jan Białostocki (Warszawa: PWN, 1988), 49-50.

13 Np. Artur Szrejter, Bestiariusz germański. Potwory, olbrzymy i święte zwierzęta (Gdańsk: Wydawnictwo Maszoperia Literacka; Gdańsk: Wydawnictwo Oskar, 2012).

14 Kobielus, Bestiarium chrześcijańskie, 20-21. 
dużej liczbie wydań miały ogromny wpływ na odkrywanie, podtrzymywanie oraz przekazywanie dawnych treści symbolicznych. Dla artystów, kaznodziejów, autorów programów symbolicznych, twórców sztuk dramatycznych i plastycznych miały one charakter wręcz wzornika-źródła. Wpływały na kształtowanie się języka komunikacji jako „przejawu marzenia o stworzeniu syntezy sztuk, o opracowaniu wspólnego 'Języka', odpowiednio skonstruowanego systemu znaków służących do uniwersalnego zastosowania, do przekazywania myśli, idei w różnych sztukach, a także dążenia do zrealizowania owych marzeń”, istniejących w bardzo rozmaitych i odległych od siebie epokach ${ }^{15}$.

Przypomnijmy, że tekst Fizjologa powstał najprawdopodobniej w Aleksandrii między II a III wiekiem naszej ery. Anonimowy autor zebrał wschodnią (perską i indyjską), egipską i grecką tradycję dotyczącą różnych gatunków zwierząt oraz właściwości kamieni, przy czym do opisu przyrodniczego dodał komentarz teologiczny o etycznym charakterze, a poszczególne zjawiska świata natury odniósł do wydarzeń starotestamentowych lub hagiograficznych ${ }^{16}$. W czasach średniowiecza Fizjologus - Physiologos („Przyrodnik”) oddziaływał silnie na bestiariusze, herbaria i lapidariusze za sprawą motywów oraz metody alegorycznej interpretacji świata natury ${ }^{17}$.

Zaspokajające potrzebę fantastyki, cudowności i egzotyki bestiariusze stanowią osobny zespół dzieł, pokrewny Fizjologowi. W europejskim średniowieczu był to niemal gatunek literacki obejmujący charakterystyki różnego rodzaju zwierząt, roślin i kamieni opatrzone komentarzem moralnym i stosownym napomnieniem. Opisywane zwierzęta były zarówno mityczne, baśniowe, legendarne, jak i rzeczywiste. Autorzy wzorowali się na Fizjologu i on też był rdzeniem, do którego dołączali teksty z innych ksiąg. Zadaniem do wykonania było wyeksponowanie człowieka na tle przyrody ${ }^{18}$.

15 Pelc, Słowo i obraz, 351.

16 Kobielus, Bestiarium chrześcijańskie, 26-27; Roman Krzywy, „Wstęp”, w Alciatus, Emblematum libellus, XVIII; Fizjologi i Aviarium: Średniowieczne traktaty o symbolice zwierząt, tłum. i oprac. Stanisław Kobielus (Kraków: Tyniec Wydawnictwo Benedyktynów, 2005).

17 Wittkower, „Hieroglyphics”, 114 - autor uważa, że Fizjologus stanowił drugą z dróg wprowadzania egipskich idei do kultury europejskiej, a powołując się na E. P. Evansa stwierdza, że poza Biblią właśnie Fizjolgus jest książką o największym wpływie na „tak wielu ludzi” przez tyle wieków; por. Edward Payson Evans, Animal Symbolism in the Ecclesiastical Architecture with Bibliography and Seventy-eight Illustrations (London: W. Heinemann, 1896), 45-91 (Chapter III, “The `Fizjologus` in Art and Literature”), dostęp 7 listopada 2016, http://bestiary.ca/etexts/evans 1896/evans\%20-\%20animal\%20symbolism\%20in\%20ecclesiastical\%20 architecture.pdf

18 Kobielus, Bestiarium chrześcijańskie, 29-30. 
Bestiariusze, powstałe z połączenia traktatów chrześcijańskiej filozofii moralnej i podręczników zoologii, oprócz celów dydaktycznych miały też pewne ambicje naukowe. Opisywały florę i faunę zgodnie z najlepszą ówczesną wiedzą opartą na dorobku starożytności, potraktowanym wszakże wybiórczo, gdyż łatwiej było przyswajać swobodne opowieści z Historii naturalnej Pliniusza niż systematyczny wykład Zoologii Arystotelesa ${ }^{19}$. W czasie największej swej popularności, czyli w XIII i XIV wieku ${ }^{20}$, bestiariusze zaczęły jednak służyć celom, które doprowadziły do powolnego zaniku tego gatunku. Stopniowo bowiem, poczynając od XIII stulecia, „pomijając pouczenie moralne ‘odzyskiwano’ z bestiariuszy część przyrodniczą, by włączyć ją do kompendiów tematycznych" ${ }^{21}$. Renesansowe podejście do świata, z jego praktycznym, a nie teologicznym zainteresowaniem zwierzętami, podważyło rację bytu bestiariuszy, choć sięgano do nich jeszcze w końcu XVII wieku. Wprawdzie można natrafić na ich kartach na rzetelne informacje, jednakże obserwacje przyrody są „naginane” do założonych z góry wniosków etycznych, głównie przez przypisanie zwierzętom ludzkich temperamentów i priorytetów. Należy dodać, że i niektóre wczesne teksty przyrodnicze nie były wolne od komentarza o charakterze symboliczno-moralizatorskim.

Hieroglify Horapollona - spisane w V wieku naszej ery w Aleksandrii, lecz uznane za prastary tekst egipski, odkryte w 1419 roku na wyspie Andros i przywiezione do Florencji trzy lata później, wydane w języku greckim w roku 1505, a w roku 1517 po łacinie i potem wznawiane - pojawiły się w środowisku włoskich humanistów w czasie nader odpowiednim. Znalazły już grunt przygotowany: rosło zainteresowanie Egiptem i jego pismem, rozwijały się badania naukowe, których ustalenia dyskredytowały historie o zwyczajach zwierząt rodem z bestiariuszy, a jednocześnie odczuwalna była potrzeba zachowania fikcji i fantazji oraz tradycji wyobrażeń o zwierzętach i upatrywania w nich metafory ludzkiego życia. Można by zakładać, że Hieroglify wniosły do dzieł z tego okresu znaczących dla sztuki i literatury tekstów o charakterze emblematycznym, kompendiów symbolograficznych i symbolicznych, zbiorów personifikacji - ładunek fantastyki przejawiającej się w wyglądzie, a szczególnie w zwyczajach zwierząt i ludzi obdarzanych ich cechami i mocami. Wydaje się jednak, że było inaczej - że Hieroglify tę

\footnotetext{
19 Anna Sawicka, „Średniowieczny bestiariusz kataloński na nowo odczytany”, w Bestiariusz, tłum. Rozalya Sasor (Kraków: Księgarnia Akademicka, 2005), 16-17.

20 Sawicka, „Średniowieczny bestiariusz”, 17.

21 Sawicka, „Średniowieczny bestiariusz”, 17.
} 
wszechobecną w kulturze europejskiej, judeochrześcijańskiej potrzebę baśniowości, fantastyki w pewnym sensie „uratowały”. Opowieści dotyczące fantastycznych zwyczajów zwierząt przetrwały mimo wyników zarówno pierwszych, jak i zaawansowanych obserwacji naukowych. Odznaczając się ponadczasowością, stanowią wyraz ogólnoludzkiej potrzeby poznawania po Stworzeniu - Stwórcy, jak pouczał zawsze chętnie w tego typu rozważaniach cytowany św. Paweł. Kiedy nie dało się utrzymać powagi dawnych tekstów opartych na starej koncepcji księgi natury, realizującej ludzkie zdolności kreacyjne albo odtwarzającej jakiś przekaz o charakterze archetypicznym, można było ten przekaz przyjąć ponownie, ale jakby z innego źródła, za pośrednictwem tajemniczej, prastarej, budzącej szacunek - także renesansowych platoników badających antyczne teksty i próbujących pogodzić ich wymowę z chrześcijaństwem - kultury egipskiej ${ }^{22}$.

Andrea Alciati (1492-1550), włoski humanista i prawnik, autor pierwszej księgi o charakterze emblematycznym Emblematum liber (Augsburg 1531), który wprost przyznawał się do inspiracji hieroglifikami Horapolla w traktacie De verborum significatione, uważał, że jego emblematy „są po części poetycką transpozycją późno starożytnego dzieła oraz nieznanej nam obecnie kolekcji hieroglifów Chajremona"23. Trzeba podkreślić, że do pracy Alciatiego z utworu Horapollona przeniesione zostały tylko pojedyncze znaki ${ }^{24}$. I choć badacze uważają, że geneza emblematyki wynika z potrzeby „stworzenia nowożytnego odpowiednika alegorycznie interpretowanych piktogramów”25, to

${ }^{22}$ O wpływie filozofii neoplatońskiej i kultury egipskiej na powstanie nowego języka sztuki w czasach nowożytnych zob. Alicja Saar-Kozłowska, „Iustitia i religio - 'dwa skrzydła' wiodące duszę w sfery wyższe. Dzieło sztuki jako wzór moralno-filozoficzny na przykładzie pomnika grobowego Anny Wazówny”, w Filozofia i sztuka. Festiwal filozofii, t. 8, red. Ewa Starzyńska-Kościuszko, Andrzej Kucner i Piotr Wasyluk (Olsztyn: Instytut Filozofii UWM, 2016), 173-179.

23 Krzywy, „Wstęp”, XVII. Chajremon (I w.) - piszący po grecku stoicki filozof; autor traktatu o hieroglifach zachowanego we fragmentach w postaci późniejszych cytowań. Zob. Sokolski, „Wstęp”, w Horapollon, Hieroglify, 8-9, przypis 9.

24 Alciati naśladował też Filippo Fasaniniego, pierwszego tłumacza tekstu Hieroglifów Horapollona na język łaciński (wyd. 1517), np. w emblemie Gratiam referendam. Por. Karl Giehlow, The Humanist Interpretation of Hieroglyphs in the Allegorical Studies of the Renaissance. With a Focus on the Triumphal Arch of Maximilian I, Translated with an Introduction \& Notes by Robin Raybould (Leiden - Boston: Brill - Hes de Graaf, 2015), 266. Por. rozdz. The hierogliphic origins of the Emblemata of Alciato (s. 236-293). Publikacja zawiera m.in. ilustracje Albrechta Dürera do tekstu Horapollona. Zob. https://books.google.pl/books?id=itguBgAAQBAJ \&printsec $=$ frontcover \&hl=pl\&source=gbs_ge_summary_r\&cad=0\#v=onepage\&q\&f=false (dostęp 22.03.2017).

25 Krzywy, „Wstęp”, XVII. 
szersze wykorzystanie hieroglifów jako podstawy w pracy Alciatiusa nie było raczej możliwe, z uwagi na nowość kodu, zbyt dużą w latach trzydziestych XVI wieku i brak oswojenia przez tradycję, jego niezrozumiałość - jeszcze wówczas - dla odbiorców. Alciati wykorzystał literaturę antyczną, teksty biblijne, ikonografię starożytną i chrześcijańską, poezję, mitologię, bajki zwierzęce, przysłowia, anegdoty, dzieła przyrodnicze, średniowieczne bestiariusze, wyobrażenia z medali i monet, aby przedstawić konstrukcje rozpoznawalne i ewokujące sensy znane odbiorcom i utrwalone w tradycji ${ }^{26}$.

Zespolenia przekazu Horapollona - budzącego fascynację i zaufanie $\mathrm{z}$ dawną tradycją antyczną i obserwacjami zwierząt, z fantastyczno-moralizatorskimi przekazami Fizjologa i bestiariów średniowiecza, dokonał Pierio Valeriano Bolzani (1477-1558). W literaturze przedmiotu przyjmuje się za Umberto Eco, że autor ten „zamiast czytać Horapollona w świetle tradycji, odczytuje ponownie tradycję w świetle Horapollona"27. Prawdopodobnie Pierio swoją wielokrotnie wznawianą i cieszącą się popularnością Hieroglifika, wydaną po raz pierwszy tuż po połowie XVI wieku, uratował fantazję i fikcję. „Przemycił” je i wysłał w przyszłość: do tekstów literatury, realizacji sztuk pięknych, umysłów ludzi, którzy z jakiegoś powodu nie mogą ich zatracić, jakby przechowywały pradawny kod, wyrażający prawdę o świecie najlepiej oddaną przez obraz-ideogram - może w stylu dawnych przekazów, pierwszych, jakie ludzkość odebrała i już zawsze powinna umieć odbierać - dla potrzeb nieznanej przyszłości, zgodnie z rdzeniem dawnego kodu albo tkwiącą w nim zapowiedzią kodu nowego.

Pierio wykorzystał autorytet Hieroglifów, złączył z tradycją i znacznie jak pisał - przekaz świętych ksiąg egipskich rozwinął na fali ich autorytetu i popularności. Jego wypowiedzi mają charakter wysoce moralizatorski: służą wychowaniu ludzi przez przykład zachowania zwierząt. Wprawdzie w przeważającej części jego traktatu tekst dominuje nad obrazem, ale wywód jest obficie ilustrowany różnorodnymi wyobrażeniami zaopatrzonymi w objaśnienia, na marginesach zaś są zapisane źródła podawanych informacji.

W świetle omówionych tu już tekstów wiemy, że pierwsze księgi przyrodnicze zawierają treści oparte na tradycji związanej z domniemaną wiedzą o zwyczajach zwierząt. Wyniki obserwacji są łączone z wykładnią o charakterze symbolicznym. Paradoksalnie, wraz z rozwojem obserwacji i wynikającej

26 Krzywy, „Wstęp”, XVII-XVIII.

27 Umberto Eco, W poszukiwaniu języka uniwersalnego, tłum. Wojciech Soliński (Gdańsk: Marabut; Warszawa: Volumen, 2002), 164; Sokolski, „Wstęp”, w Horapollon, Hieroglify, 23-24. 
z nich wiedzy o świecie zwierząt - jeśli nie o ich budowie, to o możliwym do zauważenia zachowaniu - dawne fantastyczne informacje na temat fauny nie zostały odrzucone, gdyż stała za nimi powaga autorytetów: poetów, pisarzy, filozofów oraz Kościoła. Zasada pouczenia moralnego o ustalonej już tradycji była ponad odkryciami o charakterze naukowym.

Zwyczaje zwierząt, zaobserwowane bądź (najczęściej) fantastyczne, były tak dalece istotne, że - jak wynika z tekstu Valeriana - kiedy Arystoteles przypisał afrykańskiemu ptakowi o nazwie żołna tę samą miłość wobec rodziców, co bocianowi, Elian umieścił owego ptaka w „rodzaju bocianów”; różnica miała dotyczyć jedynie miejsca zakładania gniazda przez ptaki, których wielkość i kształt były zdecydowanie odmienne. Pierio pisze też o zwierzętach, co do których istnienia i nazwy nie ma pewności ${ }^{28}$. Powołuje się na Hieroglify Horapollona wypowiadając się np. o pobożności wyniesionej ponad bezbożność. Stwierdza, że gdy zastanawiał się nad znaczeniem hipopotama, odczytywał „ów godny wspomnienia dokument Egipcjan”29, według którego królewskie berła dekorowali oni wyobrażeniem bociana ${ }^{30}$ (il. 7).

Tradycję oraz autorytet „Egipcjanina” Horapollona, zręcznie rozwinięty przez Pieria Valeriano ${ }^{31}$, umiejętnie połączył w swej pracy Cesare Ripa (ok. 1555-1622) 32. Można by podać ogromną liczbę przykładów powołania

28 Valeriano opisuje troskę o rodziców (pietas) kukufy (cucupha), ptaka, którego łacinnicy zaliczają do bocianów. Nazwa, jak „szczerze mógłby wyznać”, jeszcze nie jest mu znana i zastanawia się, czy nie chodzi o cikumę, która troszczy się o rodziców; w tej kwestii zgadza się „z tymi, którzy dowiedzieliby się pewniejszych" faktów. Podjął temat ze względu na autorytet niezwykle cenionego w jego czasach autora Hieroglifów, Horapollona. Valeriano, Hieroglyphica, 205. Cyt. za: Valeriano, Hieroglyphica, 205.

30 Valeriano, Hieroglyphica, 203-204. W kwestii pietas - pobożności symbolizowanej przez bociana - Valeriano odwołuje się do pism Horacego, wizerunku na monecie Hadriana, rzymskiego prawa (lex Pelargica - prawa bocianiego) nakazującego opiekę nad rodzicami, greckiego przysłowia „odwdzięczać się za wychowanie”, Eliana, Boecjusza, Dekalogu, Homera, Likurga, Sextusa Pompeiusa Festusa, Erazma, Meandra.

31 Interpretację nowożytnego obrazu Tycjana opartą m.in. na przekazach Horapollona, Pieria Valeriana, Cartariego oraz Iconologii Cesarego Ripy zob. np. Erwin Panofsky, “Titians Allegory of Prudence. A Postscript”, w Erwin Panofsky, Meaning in the Visual Arts. Papers in and on Art History (New York: Doubleday\&Company, Inc., 1955), 146-168, il. 28-45 (w artykule liczne odesłania do źródeł i literatury tematu).

32 Podstawą poniższych rozważań jest edycja: Cesare Ripa, Ikonologia, tłum. Ireneusz Kania (Kraków: Universitas, 1998), znaczne uboższa w stosunku do obszernego wydania z 1603 r.: Cesare Ripa, Iconologia (Roma: Appresso Lepido Faeji,1603), lecz wystarczająca do śledzenia mechanizmów kształtowania przekazu dotyczącego symboliki zwierząt na tym etapie badań. Zgodnie z notą, podstawą polskiego wydania jest wersja z 1618 r., a określenie „Edycja podręczna [...] znaczy, że tekst został skrócony tam, gdzie było trzeba, lecz nie przeredagowany ani zmodyfikowany”; zob. Pierio Buscaroli, „Nota edytorska”, w Ripa, Ikonologia, XIX. 
się przez Ripę na różnorodnych poprzedników: na Valeriana pokaźną, znaczną na Horapollona i Egipcjan, bardzo nieliczną na Alciatiusa ${ }^{33}$. Iconologia Ripy, popularna, wielokrotnie wznawiana i stosowana po kres XVIII stulecia, przeniosła i utrwaliła na wieki opinie o zwyczajach zwierząt. Dzięki niej wiadomo na przykład, że zimorodki, zgodnie z Owidiuszem i Plutarchem, obdarzają się wielką miłością ${ }^{34}$. Ognioptak to opierzone zwierzę żyjące dopóty, dopóki przebywa w ogniu, gdy ogień gaśnie, zwierzę odlatuje niezbyt daleko i wnet zdycha ${ }^{35}$. Salamandra ,jest to zwierzę podobne do jaszczurki, usiane gwiazdkami, niepokazujące się nigdy, chyba że podczas długiej słoty; w czasie pogody go nie widać. Jest to bestia tak zimna, że gasi ogień natychmiast, zupełnie jak lód. Mówi się też, że mieszka ona i żyje w ogniu ${ }^{36}$ - jak twierdzi Arystoteles, tudzież inni autorzy piszący o sprawach natury - nie tylko nie doznaje odeń żadnej szkody, ale nawet go gasi” ${ }^{37}$. Kameleon „nic nie jada ani nie pije, ale wyłącznie powietrzem karmi się i żyje”38. Z ambiwalencji swoich

33 Cesare Ripa to pseudonim Giovanniego Campani, zob. Dictionary of Art Historians, https:// dictionaryofarthistorians.org/ripacf.htm (dostęp 15 października 2015). Źródłem informacji Ripy, obok dzieła Valerianiego, była praca, o której nie wspomniał: Vincenzo Cartari, Le imagini de gli Dei delli Antichi, Venetia: Appresso Euangelista Deuchino, 1625 (wcześniejsze wydania: Venetia 1556, Venezia 1571), https://archive.org/details/leimaginideglide01cart (dostęp 15 października 2015); wśród opisanych w niej wyobrażeń, które mogły zainspirować Ripę, jest np. Cerera ze zwierzęcą głową (163), nagi mężczyzna o ciele pokrytym oczami i uszami (276), starzec z wydłużonymi zniekształconymi palcami, którego nogi pokrywają łuski, a ciało węże (324).

34 Ripa, Ikonologia, 217-219: „Zimorodek. Owidiusz w 10 ks. Metamorfoz pisze o wielkiej miłości zimorodków. Samica zimorodka [...]. Gdy bowiem skutkiem starości słabnie on i nie nadąża w locie za małżonką, bierze go na plecy, karmi go i nigdy nie opuszcza, nigdy nie zostawia samego, lecz nosi go na barkach, pielęgnuje i jest razem z nim aż do śmierci, jak o tym opowiada Plutarch".

35 Ripa, Ikonologia, 219: „Ogień. Kobieta obiema rękami podtrzymuje piękne naczynie pełne ognia; z jednej strony, pośrodku ognia, ma tam być salamandra, z drugiej również objęty płomieniem - feniks, ponad którym widać błyszczące słońce. Albo zamiast feniksa może być tam ognioptak".

36 Przekonanie, że salamandra jest zdolna żyć w ogniu, sprawiło m.in., że lekarz i przyrodnik Paracelsus (1493/1494-1541) pisał także o ludziach żyjących w ogniu zwanych Salamandrami (lub ludźmi ogniowymi); twierdził, że „ogień jest ich powietrzem, tak jak nasze powietrze jest naszym powietrzem [...]. Dla salamandrów podłożem jest ziemia, a niebem powietrze, ogień zaś jest ich chaosem, tak więc pokarm rośnie im z ziemi i ognia, a konstelacja z powietrza jest ich niebem" - zob. Paracelsus, O nimfach, sylfach, pigmejach $i$ salamandrach, etc., tłum. Robert Urbański, wstęp i komentarz Jacek Sokolski (Wrocław: Oficyna Wydawnicza ATUT - Wrocławskie Wydawnictwo Oświatowe, 2013), 56-57, 80, przypis 16, 30.

37 Ripa, Ikonologia, 219 - autor powołał się na Historię naturalnq̨ Pliniusza Starszego (ks. 10, rozdz. 67).

38 Ripa, Ikonologia: „Powietrze. Niewiasta z włosem rozwianym na wietrze; siedząc na chmurach trzyma w dłoni pięknego pawia, ptaka poświęconego Junonie, bogini powietrza. Widać 
komentarzy dotyczących zwierząt i roślin („Na przykład lew jest hieroglifem zarówno łagodności, jak też wściekłości ${ }^{39},[\ldots]$ cyprys jest symbolem śmierci i wieczności, migdał - młodości i starości” ${ }^{30}$ ) Ripa tłumaczył się odwołując się do wypowiedzi poetów.

Wszystkie te dawno już opisane zwyczaje zwierząt zostały przedstawione w tekście Ripy z końca XVI wieku, a przyjmowano je jako odpowiadające rzeczywistości jeszcze w wiekach następnych, chociaż w XVII stuleciu przyspieszył rozwój badań i obserwacji naukowych, a pewnie nikt nie zobaczył salamandry w ogniu ${ }^{41}$. Już wtedy bowiem - mimo ogromnego autorytetu sta-

tam też latające w przestworzu rozmaite ptactwo, u stóp zaś owej postaci znajduje się kameleon, zwierzę nic nie jada ani nie pije, ale wyłącznie powietrzem karmi się i żyje. Donosi o tym Pliniusz w ks. 10,8, rozdz. 33".

39 Ripa, Ikonologia, 177: „Szał i wściekłość - Mąż zbrojny o wyglądzie przerażającym i dzikim, z twarzą barwy czerwonej, z obnażonym mieczem w prawej dłoni [...]. Na lewym ramieniu ma tarczę, pośrodku której widnieje lew. Tak figurę tę opisuje Alciato”. Lew jest także symbolem Czujności, którą przedstawia kobieta stojąca z dzwonkiem w dłoni i lwem obok siebie. Lew śpi z otwartymi oczami - Ripa, Ikonologia, 244.

40 Ripa, Ikonologia, 421-422: „Zapomnienie - Starucha w wieńcu uplecionym z mandragory, prawą ręką przytrzymująca skrępowanego rysia, w lewej dzierży gałązkę jałowca”. Ripa tłumaczy się z tego, że te same motywy wykorzystuje jako symbole różnych cech: „Wcześniej jałowiec przeznaczyliśmy na wieniec symbolizujący pamięć o doznanych dobrodziejstwach, jakże tedy obecnie oddajemy go do rozporządzenia zapomnieniu? Ta sprzeczność nie jest zgoła przeszkodą, byśmy przydzielili go obojgu, gdyż podobnie jak zwierzę z racji rozmaitych cech swej natury może być symbolem rożnych, i to sprzecznych wzajem rzeczy (na przykład Lew jest Hieroglifem zarówno łagodności, jak też wściekłości), tak też roślina z różnych powodów i przez wzgląd na różne sytuacje, wyimaginowane przez Poetów, może wyobrażać wiele różnych, nawet sprzecznych z sobą spraw”. Moc - „w baśniach Poetów mocnym nazywany jest Herkules, a także inni [mocarze] w wielu innych miejscach, zmagający się z lwami i pokonujący je" - Ripa, Ikonologia, 101-103.

${ }^{41}$ Por. Jacek Sokolski, „Wstęp”, w Pseudo-Albert Wielki, Księga sekretów o cnotach ziół, kamieni i zwierząt niektórych, oprac. Jerzy Kroczak et al. (Wrocław: Oficyna Wydawnicza ATUT - Wrocławskie Wydawnictwo Oświatowe, 2014), 7, 34-36. Autor pisze, że wprawdzie scholastyczni pisarze odwoływali się do bezpośredniej obserwacji, lecz nie była dla nich niezbędna, gdyż często korzystali z obserwacji opisanych w pracach swoich poprzedników, np. Arystotelesa; „Ich doświadczenie to zwykle tylko swoiste eksperymenty mentalne, dokonywane, jak to niekiedy sami przyznawali, secundum imaginationem” - Sokolski, „Wstęp”, w Pseudo-Albert Wielki, Księga, 35 - a w przyrodniczych dociekaniach ogromna rola wyobraźni była „największym chyba odstępstwem od Arystotelesowskiego modelu, który teoretycznie w pełni akceptowali” - Sokolski, „Wstęp”, w Pseudo-Albert Wielki, Księga, 35. Niektóre informacje i eksperymenty opisane przez greckich i arabskich autorów nie dawały się powtórzyć i potwierdzić, np. o strusiach jedzących żelazo - Albert Wielki (1193/1205-1280) sprawdzał je bez powodzenia na cesarskich strusiach, dopiero 400 lat później wielki miłośnik naukowych eksperymentów, uczony jezuita Athansaius Kircher (1602-1680) spotkał na Malcie afrykańskie ptaki, które chętnie jadły kawałki żelaza; mit zatem nie został obalony, a raczej przywrócony do życia. Zob. Athanasius Kircher, Arca Noë, in tres libros digesta, sive de rebus ante 
rożytnych, który czasem bardzo pomagał, a często przeszkadzał w zaakceptowaniu pewnych obserwacji - doszło do „zgody” na rozdwojenie dróg nauki i literatury. Ripa zresztą otwarcie przyznał, że opisuje to, co się przyśniło poetom. Uporządkowanie relacji stricte naukowych nastąpiło w wieku XVIII.

Warto jednakże zapytać, skąd się brała wiedza i wyobrażenia o zwyczajach zwierząt, często fikcyjnych i fantastycznych. Czy była efektem obserwacji? Jednostkowych czy wielokrotnych? Prowadzonych osobiście czy też opartych na opowieściach zasłyszanych, fantastycznych, fikcyjnych, pożądanych i powtarzanych tak często, że prawie stały się prawdą? Najlepiej odwołać się do argumentacji samego Cesarego Ripy i jego przepisu na personifikację Płodności. Otóż wyjątkowość tej cechy u ptaka Akanta scharakteryzował on na podstawie tego, co Pierio (Valeriano) widział w Padwie i co zostało stwierdzone w pismach Alberta ${ }^{42}$ (czyli Ripa nie miał własnych doświadczeń). Podobnie już w starożytności Elian (ok. 175-ok. 235), autor zbioru opowiadań o osobliwościach zwierząt, zastrzegał się w kwestii prawdziwości przekazywanych informacji: „osobiście w to nie wierzę” lub „o ile można ufać temu autorowi”, a także „włożę to między bajki” i wreszcie: „,nie wiem, jak jest naprawdę, ale słyszałem, więc przekazuję"43.

Ripa rozwinął tendencje zarysowujące się już w wydaniach emblematycznych - gdzie konstrukcje słowno-obrazowe dzielone były na poszczególne tematy w dążeniu do wypracowania uniwersalnego kodu - i sformułował przepisy na obrazowanie personifikacji abstrakcyjnych pojęć w postaci ludzi i jednego drzewa (oliwka jako Miłość w wydaniu z 1603 r. ${ }^{44}$ ). Posługiwał się także atrybutami mającymi symboliczne znaczenie, którego wykładnia wprowadzała i uzasadniała treść oraz wybór kwestii tak tu istotnych, jak płeć, wiek, uroda, postawa, odzienie. Atrybuty chromatyczne precyzujące barwę stroju również wprowadzały określone przesłanie o charakterze sym-

diluvium, de diluvio, et de rebus post diluvium a Noëmo gestis (Amstelodami: apud Johannem Janssonium \& Waesberge, 1675), 78 (“ferro avide inhiat”), dostęp 7 listopada 2016, http:// gallica.bnf.fr/ark:/12148/bpt6k111864r/f102.item.zoom

42 Ripa, Ikonologia, 133.

43 Klaudiusz Elian, O właściwościach zwierząt (wybór), tłum., wstęp i przypisy Anna M. Komornicka (Warszawa: Prószyński i S-ka, 2005), 20 - autorka wstępu pisze, że niektóre informacje Eliana o zwierzętach są wiarygodne, inne zbliżone do baśni, w których roi się od fantastycznych stworów, takich jak wielki tuńczyk, wielki wąż, gryf, jednorożec albo martichoras (w języku perskim 'pożerający ludzi'; tygrys lub mitologiczne zwierzę z ludzką twarzą, zaopatrzone w jadowite kolce - Elian, O właściwościach, 85); podkreśla też, że kilka mitycznych bestii zostało później zidentyfikowanych jako należące do fauny (hipopotam, tygrys, wieloryb).

44 Ripa, Iconologia, 65 (Carita). 
bolicznym ${ }^{45}$. Prosto i wydatnie wzmacniały symboliczną wymowę wizerunku drobne atrybuty: dodatki do odzieży, zdobiące ją wzory, np. w formie oczu lub uszu $^{46}$ (il. 9), a także banderole ze stosownymi napisami ${ }^{47}$. Funkcje atrybutów pełniły też rośliny, zwierzęta oraz różnorodne przedmioty. Ripa pojmował atrybuty jako hieroglify - czyli znaki, ideogramy ewokujące określone treści ideowe ${ }^{48}$. Tak samo podchodził do egipskich hieroglifów i symbolicznego znaczenia zwierząt. Napisał m.in., że słoń „pośród liter Starożytnych Egipcjan figuruje jako wybitny symbol łagodności” ${ }^{49}$, a „Hieroglifem miłości ojcowskiej jest Bocian" ${ }^{50}$, wyrażając tym samym dobitnie ówczesne rozumienie egipskiego pisma i to, że prawdziwie tkwił w wielkiej pomyłce polegającej na nierozumieniu go. Hieroglify, jak można się przekonać, miały też różną moc i „zawartość” prawdy albo siłę przekonywania. Na przykład w przepisie na „Siłę ujarzmioną przez sprawiedliwośc” ${ }^{51}$ lew, na którym siedzi ubrana po królewsku niewiasta chwytająca za miecz, oznacza siłę i jest to jego „praw-

45 Ripa, Iconologia: Ciekawość - w czerwono-błękitnym stroju oznaczającym żądzę wiedzy (21); Gniew - niewiasta w czerwonej szacie wyszywanej na czarno (38).

46 Ripa, Iconologia: np. Kłamstwo - suknia młodej kobiety dekorowana maskami i językami (86-87); Dociekanie - suknia usiana mrówkami, symbolami dociekliwości u Egipcjan (28-29); Dobrotliwość - suknia usiana złotymi gwiazdami, jak życzliwe dla nas niebo (27-28); Ciekawość - czerwono-błękitna suknia usiana gęsto wizerunkami uszu i żab symboli ciekawości (21-22); Niebo - szata usiana gwiazdami (107-108); Wesele - suknia z wymalowanymi zielonymi gałązkami oraz czerwonymi i żółtymi kwiatami (197-198); Wieczność - niebieska szata z gwiazdami (200-201); Zazdrość - oczy i uszy wymalowane na szacie (210-211); Poezja - szata błękitna wymalowana w gwiazdy (321-322); Racja stanu - suknia błękitnego koloru haftowana w oczy i uszy szpiegów (354-356); Szpieg - płaszcz z wymalowanymi oczami, uszami i językami (381-382).

47 Ripa, Iconologia: np. Cna wstydliwość - napis na banderoli: DYSORDIA PROCUL - „wystrzegaj się przesadnej wstydliwości” (233); Kredyt - napis na księdze: „Solutus omni foenore” „wolny od wszelkiego długu” (89); Pomysłowość - napis na sukni: „non aliunde” („znikąd”), na bransoletce prawej dłoni: AD OPERAM („Do dzieła”) (462) .

48 Ripa, Iconologia, 259: np. „symbolem hieroglificznym [wojny] jest włócznia”. Włócznię trzyma jako symbol wojny wydanej wspólnemu wrogowi każda $\mathrm{z}$ dwu uzbrojonych i obejmujących się kobiet personifikujących Ligę.

49 Ripa, Iconologia, 262: Słoń walczy tylko ze słabszymi albo z silniejszymi od siebie: „pośród liter starożytnych Egipcjan figuruje jako wybitny symbol łagodności także dlatego, że idąc pośród stada Owiec, które plączą mu się pod nogami, usuwa się na bok, aby tylko skutkiem własnej nieostrożności nie napytały sobie biedy".

50 Ripa, Iconologia, 225-226: Afekt synowski wobec ojca - Ripa pisze, że o miłości Eneasza niosącego na plecach swego ojca „śpiewał Wergiliusz w 2 pieśni Eneidy; Alciato dał jej wyraz w Emblemacie 194".

51 Ripa, Iconologia, 164-165: „Niewiastę objaśniano jako Sprawiedliwość”. 
dziwy hieroglif”. W przepisie na personifikację Religii pojawia się słoń, gdyż jest on „hieroglifem religii” ${ }^{2}$.

Należy podkreślić, że zwierzęta nie tylko uosabiały ludzkie cechy, ale też użyczały części swoich ciał gwarantujących ikonologicznym personifikacjom nieosiągalne dla człowieka możliwości. Przykładem jest tu Pogląd ze skrzydłami u ramion i dłoni, co umożliwiało mu natychmiastowe obiegnięcie całego świata, „nader często przyodzianego w szaty niewiedzy”53. Personifikacja Zobowiązania ${ }^{54} \mathrm{o}$ dwóch głowach i czterech ramionach jest przykładem dalej posuniętej hybrydyzacji postaci człowieka, wprowadzonej dla wyrażenia określonej idei - wygląd postaci pokazuje, że człowiek biorący na siebie zobowiązanie ma dwie osobowości. Dwie twarze mają personifikacje Prudencji oraz Teologii ${ }^{55}$. Perswazja trzyma uwiązane zwierzę o trzech głowach - psa, kota i małpy, dla określenia pożądanych dla niej cech: życzliwości, uległości i natężenia uwagi ${ }^{56}$.

Ripa powoływał się na wielu autorów i liczne teksty, a także na dzieła sztuki, zarówno dawnej, antycznej, jak i nowożytnej, na przykład rzeźby Michała Anioła przeznaczone do grobowca Juliusza II, personifikujące vita activa i vita contemplativa ${ }^{57} \mathrm{w}$ postaciach Lei i Racheli. Podał również przepisy na obrazowanie potworów, wyjaśniając: „często się zdarza, że trzeba przedstawiać rozmaite ziemne, wodne i powietrzne Monstra, wyszukałem kilku poetów, którzy o nich wspominają. Myślę, że dobrze będzie zamieścić

52 Ripa, Iconologia, 356-357: „Kobieta z obliczem przysłoniętym cieniuchnym welonem, w prawej ręce trzymająca Księgę i Krzyż, na lewej dłoni ma płomień, obok siebie zaś - Słonia, bardziej od innych zwierząt nabożnego, będącego Hieroglifem religii. Opowiada Pliniusz, że ma on w uwielbieniu Słońce i Gwiazdy, kiedy zaś pojawia się Księżyc w nowiu, z własnego popędu idzie do rzeki, aby się obmyć, a gdy zachorzeje, przyzywa pomocy Niebios podrzucając ku Niebu pęki traw, aby tam orędowały za jego wyzdrowieniem”. Funkcje hieroglifów pełnią też rośliny. Np. hieroglifem naszego ziemskiego bytowania jest róża, rozkwitająca jako ostatnia po wszystkich innych kwiatach, ginąca zaś jako pierwsza („Życia krótkotrwałość” - Ripa, Iconologia, 438).

53 Ripa, Iconologia, 323: np. skrzydełka na skroniach świadczące o szybkości działania ma Wyobraźnia (486-488), a dla oznaczenia wysokiej pozycji całej sfery umysłowej Pomysłowość (462-463), skrzydła na plecach szybko kończąca się Przyjemność (352-353) oraz Wola, by w locie przemierzać świat i wzbijać się ku niebu (413), skrzydła na plecach i skrzydełka u stóp ma personifikacja Przesilenia letniego (348-349) oraz Szybkość (382-383), a parę skrzydełek u głowy Matematyka, by za pośrednictwem umysłu wzbijać się do lotu (265-267).

54 Ripa, Iconologia, 433.

55 Ripa, Iconologia, 363-365 (Roztropność), 394-395 (Teologia).

56 Ripa, Iconologia, 311-312.

57 Ripa, Iconologia, 438-439 (Życie czynne, Życie kontemplacyjne). 
tutaj wszystkie razem, przemieszane, bo może komuś się to przyda"58. Tym samym utrwalił i rozpropagował istoty fantastyczne. Jak można się przekonać z lektury jego pracy, symbolika zwierząt uznana za pochodzącą z egipskiej starożytności nie tyle wywodziła się wprost z Hieroglifiki Horapollona, ile została przeniesiona i utrwalona za pośrednictwem Hieroglyphica Valeriana, czego dowodzą liczne wskazania Ripy.

Zwróćmy zatem uwagę na niektóre przepisy Cesarego Ripy, w których powołał się on na autorytet Pieria Valeriana. To Pierio miał stwierdzić - żeby wymienić parę przykładów jego opinii przytoczonych przez Ripę - że „Usposobienie przyjemne, łatwe i przyjazne” wyobrażane ma być przez delfina ${ }^{59}$. Dobroć to piękna kobieta z pelikanem z pisklętami ${ }^{60}$. Ignorancja pokazywana ma być z nietoperzem, ponieważ - jak mówi Valeriano - „do światła podobna jest mądrość, do ciemności zaś, których nigdy nie opuszcza Gacek, ignorancja” ${ }^{61}$. Ciekawość to niewiasta w czerwono-błękitnym stroju gęsto usianym wizerunkami uszu i żab, gdyż według Valeriana oczy żaby zawiązane w jelenią skórę wraz z mięsem słowika sprawiają, że człowiek będzie bystry, trzeźwy i ciekawy ${ }^{62}$. Zdaniem Pieria Valeriana lew sczepiony z dzikiem oznacza „Moc

58 Ripa, Iconologia, 337-339: Ripa opisał Scyllę według Homera i Sekstusa Pompejusza, Charybdę, Chimerę, Gryfa, Sfinksa, Harpie, Hydrę oraz Cerbera.

59 Ripa, Iconologia, 195: wyobraża je Delfin niosący na grzbiecie chłopczyka. „Wprawdzie Pierio Valeriano, idąc za autorytetem Pauzaniasza, czyni z delfina symbol wdzięczności”, na podstawie opowieści o delfinie uwolnionym przez chłopca z sieci rybaków i uleczonym z ran, za co przypływał do niego do brzegu i nastawiał mu swój grzbiet, stąd przypisuje się mu „usposobienie przyjemne i łatwe wobec człowieka, Delfin jest miły nie na skutek jakichś otrzymanych czy też spodziewanych dobrodziejstw, lecz z racji przyrodzonej natury".

60 Ripa, Iconologia, 25-26: Dobroć - „piękna kobieta w złocistej szacie i wieńcu z ruty na głowie, ze wzrokiem zwróconym ku niebu. Na ręku trzyma pelikana z pisklętami, u jej boku, na brzegu rzeki, rośnie zielone drzewko”. Pierio Valeriano „tu i ówdzie wspomina o tym”, że pelikan, „który - wedle racji rozmaitych autorów - pragnąc ratować własne dzieci, co znalazły się w biedzie, krew sobie z żył wypuszcza, aby je nakarmić”. Dusza rozumna i szczęśliwa ma gwiazdę nad głową, bo zdaniem Valeriana gwiazdy jako symbolu nieśmiertelności duszy używali już Egipcjanie (31). „W charakterze Hieroglifu Bystrości umysłu oraz siły inteligencji Egipcjanie i Grecy malowali Herkulesa z łukiem w jednej dłoni, a w drugiej ze strzałą zakończoną trzema grotami, co miało znaczyć, że człowiek, posługując się swym mocnym i bystrym umysłem, docieka rzeczy niebieskich, ziemskich i piekielnych, albo - jak pisze Pierio Valeriano - naturalnych, boskich i matematycznych" (15-16).

61 Ripa, Iconologia, 45-46: Intelekt ma być wyobrażany w wieńcu gorczycznym na głowie albo w złotej koronie, gdyż według Pieria gorczyca rozpala usta i odciąża głowę (47).

62 Ripa, Iconologia, 21-22. Zob. też np. Jasność („wedle wykładu Pieria Valeriana (ks. 44) [...] człowiek sławę zdobywa szlachetnością albo cnotą”, dlatego jest „otoczona wielkim blaskiem”) (82); Łakomstwo (wyobraża je kobieta siedząca na wieprzu, ponieważ według Pieria zwierzęta te są łakome) (94); Krnąbrność (kobieta z osłem trzymanym za uzdę wspierająca się na wieprzu, ponieważ według Pieria „zwierzę to jest bardziej od wszelkich innych 
ducha w złączeniu z krzepą cielesną, jako że lew przystępuje do działania rozważnie i z umiarkowaniem, podczas gdy dzik, niewiele myśląc, na oślep rzuca się w każde przedsięwzięcie"63. Panowanie wyobraża mąż w dostojnej i bogatej szacie trzymający w lewej ręce berło z nasadzonym na nie okiem: „Jego głowę otacza jakby korona z węża, gdyż - jak mówi Pierio Valeriano w ks. 15 - jest on wymowną oznaką władzy”, ponieważ Septymiuszowi Sewerowi w ten sposób została przepowiedziana godność cesarska ${ }^{64}$. „Panowanie nad samym sobą wyobraża mężczyzna dosiadający lwa, który w paszczy ma wędzidło, a u starożytnych Egipcjan Lew był symbolem ducha i jego mocy, stąd Pierio Valeriano powiada, że w wielu miejscach z dawnych epok można zobaczyć takie właśnie wizerunki mające wskazywać, że rozum winien powściągać serce, gdyby zbytnio się rozzuchwaliło, bądź też pobudzać je, gdyby groziła mu gnuśność i ospałość”55.

nierozumne i niepokorne”) (91); Chwiejność bądź Niestałość w Miłości (kobieta z gałązką oliwną i zielem lebiodki oraz rybą zwaną Polipem, z której według Pieria czyniono „Hieroglif wytrwałości i stałości miłosnej, gdyż owa ryba tak mocno czepia się głazów i raf, że łatwiej ją rozszarpać na sztuki, niż od nich oderwać”) (19); zob. też Roztropność (363) - oplatająca jej ramię ryba Remora, przyczepiająca się do okrętów i powstrzymująca je, została opisana także u Pieria; zob. Joannis Pieri Valeriani Bellunensis, Hieroglyfica Sive de Sacris Aegyptiorum Aliarvmquae Gentium Literis (Coloniae Agrippinae: apud Joannem Wilhelmum Friessem bibliopolam, 1685, 212); Chyżość (kobieta z piorunami, delfinem i krogulcem, według Valeriana symbolami chyżości) (20); Obrona przed niebezpieczeństwami (kobieta z mieczem i tarczą z wyobrażonym jeżem; według Pieria tarcza dana jest jej na znak obrony; , jeż był dla Egipcjan hieroglifem obrony”) (118-119); Płodność (kobieta w wieńcu gorczycznym przyciskająca do łona ptaka Akanta albo szczygła, z pisklętami w gnieździe; u jej stóp zajęczyca z potomstwem oraz kura z pisklętami; dla określenia wielkiej płodności kur Pierio podawał, że czytał w Padwie, iż w pewnej miejscowości w Macedonii z 22 jaj wylęgły się 44 pisklęta) (133); Pochlebstwo (jak odmalowują je Horapollon i Valeriano - niewiasta grająca na flecie z jeleniem u stóp, ponieważ zwierzę to ukołysane dźwiękiem instrumentu „nieomal zapomina o samym sobie i daje się łatwo złapać") (134); Rada (mężczyzna z wisiorem w kształcie serca oraz z książką i sową; Pierio pisał, że „Egipcjanie symbolem rady czynili serce, bo prawdziwa i doskonała rada płynie z serca”, to, że rodzi się z mądrości oznacza księga, sowa poświęcona była Minerwie, „przez pogan uważanej za boginię Mądrości i rady”) (151); Przesąd („starucha z Sową na głowie i Puchaczem u stóp” oraz wroną; z sową na głowie, „gdyż osoby lękliwe i przesądne mają ją za zwierzę złowróżbne; będąc ptakiem nocnym, figuruje ona jako symbol śmierci u Pieria Valeriana, który mówi, że jej krzyk pośród nocy zawsze zapowiada jakieś nieszczęście”) (348); Rywalizacja (według Valeriana oznaczają ją „dwa barany wyzywające się do różnych zmagań") (367).

63 Ripa, Iconologia, 103.

64 Ripa, Iconologia, 127. Gdy cesarz przebywał w oberży głowę owinął mu wąż, po czym „oddalił się nie czyniąc mu żadnej krzywdy".

65 Ripa, Iconologia, 127-128. 
Według zaleceń Horapollona Ripa proponował przedstawiać m.in. Naukę Pochlebstwo, Siłę ${ }^{67}$, Słabowitość ${ }^{68}$, Wdzięcznośćc ${ }^{69}$, Miłosierdzie ${ }^{70}$. Na przykład Pochlebstwo to „niewiasta w szacie szytej misternie i wytwornie, grająca na flecie, z uśpionym jeleniem u stóp, tak odmalowuje ją Horapollon i Pierio Valeriano w swych hieroglifach, bo - jak piszą niektórzy - jeleń ma taką naturę, iż ukołysany dźwiękiem fletu nieomal zapomina o samym sobie i daje się łatwo złapać"71.

Według Egipcjan - zdaniem Ripy - „żaby, jako istoty wielkookie, są symbolem ciekawości; tak też traktowali je Starożytni, skąd Egipcjanie, pragnąc

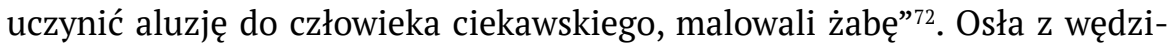
dłem w pysku ukazywali ze względu na jego krnąbrność, gdyż bydlę to zupełnie nie jest podatne na naukę ${ }^{73}$. Jeż był dla Egipcjan „hieroglifem obrony, toteż oznaczali nim człowieka nieobawiającego się zasadzek, niebezpieczeństw ani żadnych wypadków Losu”, gdyż zwierzę to kuli się w niebezpiecznej sytuacji ${ }^{74}$. Współczucie, stosownie do zasad Egipcjan, wyobrażała niewiasta w lewej ręce trzymająca gniazdo z sępem, który dziobiąc sobie uda daje pisklętom własną krew jako pokarm ${ }^{75}$. Wspomniana już Perswazja to „matrona przystojnie odziana, z piękną fryzurą, na której znajduje się język. Skrępowana jest sznurami i więzami ze złota, obu dłońmi przytrzymuje powróz, do którego uwiązane jest zwierzę o trzech głowach - Psa, Kota i Małpy. Język,

66 Ripa, Iconologia, 105: Nauka - niewiasta w poważnym wieku (na il. siedzi na zwierzęciu niedźwiedziu?), na którą spada z nieba obfita rosa, co oznacza „podług autorytetu Egipcjan, jak o tym mówi Horus-Apollo, naukę, gdyż, tak jak rosa wydelikaca młode rośliny, a stare czyni twardymi, tak też umysły naginające się z własnej woli nauka ubogaca dając z samej siebie, innych zaś, ignorantów z natury, niecha i pozostawia na stronie”.

67 Ripa, Iconologia, 163-164: Siła - kobieta z byczymi rogami na głowie (obok niej słoń z wyprężoną trąbą), ponieważ - „jak czytamy u Horusa Egipcjanina [...] - Egipcjanie, pragnąc zaznaczyć, że ktoś jest silny, przedstawiają go w postaci tego zwierzęcia, na toż samo wskazują również rogi, zwłaszcza byka".

68 Ripa, Iconologia, 168: „Horus Egipcjanin w swych Hieroglifach” napisał, że starożytni anemonem oznaczali chorobę.

69 Ripa, Iconologia, 197. W sprawie nieodzownej gałązki łubinu stanowiącej obok bociana atrybut Wdzięczności Ripa odwołał się do Historii naturalnej Pilniusza Starszego (ks. 18, rozdz. 14).

70 Ripa, Iconologia, 288-289: Miłosierdzie - w Piśmie św. jego symbolem jest wieniec oliwny, według Valeriana gałąź cytrynowca; „kawka oznaczała u Egipcjan miłosierdzie, jak można przeczytać u Horusa Apollina”.

71 Ripa, Iconologia, 134.

72 Ripa, Iconologia, 21.

73 Ripa, Iconologia, 91.

74 Ripa, Iconologia, 118-119.

75 Ripa, Iconologia, 204-205. 
jako główny i najbardziej niezbędny instrument do przekonywania innych, maluje się umieszczony na fryzurze; tak robili starożytni Egipcjanie dla ukazania wymowy i perswazji nieozdobnej, wspomaganej tylko przez naturę"76. Z drugiej strony „Egipcjanie twierdzili, że właśnie Krokodyl jest symbolem rozpusty, bo jako zwierzę niesłychanie płodne rodzi mnóstwo potomstwa"77. Równość należy przedstawiać z figurą jaskółki w gnieździe, gdyż Egipcjanie w ten sposób „ilustrowali człowieka rozdzielającego dziedzictwo po równi między swe potomstwo"78. W księdze 13 Pierio Valeriano opowiada, że „Egipcjanie, pragnąc dać symbol samotnika, malowali Zająca w swej norze, ponieważ zwierzę to żyje samotnie, toteż rzadko się zdarza, by w jednej norze przebywały dwa; albo też, jeżeli sąsiadują z sobą, zawsze oddziela je co najmniej jedna skiba ziemi”79.

Zalecenia Alciatiusa Ripa uwzględnił w przepisie na „Wróżbę złą”, którą przepowiada m.in. przebiegająca łasica ${ }^{80}$, na „Afekt synowski wobec ojca” ${ }^{81}$, na „Szał i wściekłość” 82 .

Ripa raczej nie tworzył samodzielnie fantastycznych stworów, ale wykorzystywał to, co zostało już stworzone. Powoływał się na różne autorytety, wybierał, fantazjował, ale przede wszystkim kompilował. Ludziom dodawał jako atrybuty zwierzęta lub elementy ich ciał (np. węże, ptaki) i w ten sposób wprowadzał odpowiednią tematykę, a głównie charakteryzował zwyczaje zwierząt, choć nie korzystał z własnych obserwacji. Dodając np. skrzydła głowom, stopom, dłoniom, przenosił na człowieka cechy danego zwierzęcia i moc jego skrzydeł - wyobrażając w ten sposób lot, prędkość, wolność.

Na grunt zdecydowanie moralizatorski i chrześcijański fantastykę zwierzęcą przeniósł z powrotem Filippo Picinelli w swym wielokrotnie wznawianym, cieszącym się zainteresowaniem - i co ważniejsze, przeznaczonym do

76 Ripa, Iconologia, 311.

77 Ripa, Iconologia, 362.

78 Ripa, Iconologia, 366.

79 Ripa, Iconologia, 369.

80 Ripa, Iconologia, 203-204: „O łasicy powiedział Alcjatus [...] jeśli w czasie pracy wybiegnie ci naprzeciw łasica, unikaj jej, bowiem to występne zwierzę wróży zły los [...]. To samo oznacza wrona, dlatego Pseudowergiliusz powiedział w Bukolikach [...] wrona siedząca w wydrążonym dębie często wróżyła nieszczęścia”.

81 Ripa, Iconologia, 225-226: Ripa wskazał emblemat 194.

82 Ripa, Iconologia, 177. Zob. przyp. 38 
kształtowania słowa o charakterze perswazyjnym - dziele Mundus Symbolicus (pierwsze wydanie: Mondo symbolico, Milano 1653) ${ }^{83}$.

Nowy język obrazowania idei oraz symboliczna wykładnia różnych elementów ludzkiego świata powstawały w pierwszych wiekach nowożytności. Silne w nich odwołania do tradycji starożytnego Egiptu i fascynacji nim antycznych filozofów greckich pozwalają szukać ich początków w ponaddwutysiącletniej tradycji, która nadal jest aktualna. Symbolika konstruowana na podstawie wyglądu i zwyczajów fantastycznych i fikcyjnych zwierząt jest wciąż żywa i potrzebna, a nawet więcej - znakomicie adaptowana do czasów współczesnych przez sztuki plastyczne, literaturę i film, a także popularne gry komputerowe ${ }^{84}$ (il. 10). Jesteśmy w fazie intensywnych kulturowych przemian, które podlegają i będą podlegać w przyszłości badaniom podobnym w charakterze do podjętej tu próby.

83 Filippo Picinelli, Mundus Symbolicus in Emblematum Universitate Formatus, Explicatus, et tam sacris, quam profanis Eruditionisbus Sententiis illustratus: Subministrans Oratoribus, Praedicatoribus, Academicis, Poetis etc, innumera conceptum argumenta; Idiornate Italico conscriptus a Reverendissimo Domino, D. Philippo Picinello Mediolanensi, Canonico Regulari Lateraren. Abbate, Theologo, Lectore, Praedicatore privilegiato; Nunc verò Justo Volumine auctus et in latinum traductus à R. D. Augustino Erath, Imperialis Collegi ad B. V. in Wettenhausen; Ord. S. Augustini Canonico Regulari, SS. Theologiae Doctore ac Professore, Protonotario Apostolico ac Sub-Decono, Tomus Primus; Cum quadruplici copiosissimo Indice, Lemmatum, Applicationum, Rerum notabilium, et locorum S. Scripturae. Nunc primum in Germania prodit (Coloniae Agrippinae: Sumptibus Hermanni Demen, 1687?). Zob. Dietrich Donat, „Bibliographischer Beitrag”, w Filippo Picinelli, Mundus Symbolicus (Hildesheim-New York: Georg Olms Verlag, 1979), 32; Jacek Sokolski, Słownik barokowej symboliki natury. Tom wstępny. Barokowa księga natury (Wrocław: Wydawnictwo UWr, 2000), 111, przypis 63 i 64. Zob. też Alicja Saar-Kozłowska, „Symbolika perły. Przyczynek do badań nad wykorzystaniem motywu perły w ikonologii i emblematyce", w Dawna i nowsza biżuteria w Polsce. Materiały z VIII sesji naukowej z cyklu „Rzemiosło artystyczne i wzornictwo w Polsce”, Gdańsk 14-15 marca 2007 (Toruń: SHS, 2008), 11-43.

84 Bestiariusze, baśnie i podania ludowe są podstawowym źródłem inspiracji przy tworzeniu większości współczesnych gier fantastycznych, zwłaszcza konstruowaniu postaci przeciwników gracza i / lub zaludnianiu świata gry. Autorzy kreują własną mitologię. Reinterpretując dawną symbolikę, wykorzystują ją do swych celów swobodnie korzystając z dorobku przeszłości. Wiele gier ma własne strony Wiki, budowane na wzór Wikipedii, gdzie są podane informacje dotyczące świata danej gry, od określenia jej mitologii po opis parametrów mających pomóc w zrozumieniu zasady gry. Wytwórnie filmowe coraz częściej decydują się na tworzenie kolejnych części tej samej serii lub też nowych historii osadzonych w znanym już widzom fantastycznym świecie, szerząc wiedzę o jego fikcyjnych wytworach. Pionierskie były w tym względzie książki, np. Władca pierścieni i Silmarilion Johna Ronalda Reuela Tolkiena. Firmy wydające komiksy od lat spajają ich historie w światy mające własną mitologię, a nawet fantastyczne dziedziny wiedzy. 


\section{Bibliografia}

\section{Druki i opracowania}

Alciatus, Andrea. Emblematum libellus. Książeczka emblematów. Tłumaczenie i komentarze pod kier. Mieczysława Mejora: Anna Dawidziuk, Bianka Dziadkiewicz, Ewa Kustroń-Zaniewska, wstęp i oprac. Roman Krzywy. Warszawa: Wydział Polonistyki UW, 2002.

Ashworth Jr, William B. „Emblematic Natural History of the Renaissance”. W Cultures of Natural History, red. Nicholas Jardine, James A. Secord i Emma C. Spary, 17-37. Cambridge: University Press, 1996. Dostęp 7 listopada 2016. https://books.google. pl/books?id=z9_Z9UbUIeQC\&printsec=frontcover \&hl=pl\#v=onepage \&q\&f=false; http://www.gbv.de/dms/bs/toc/187414327.pdf; http://www.academia.edu/5359347/ Cultures_of_Natural_History.

Bakke, Monika. „Wyobrażone ciałem się staje. O hybrydach, monstrach i istotach postludzkich”. W O wyobraźni, red. Ryszard Liberkowski, Włodzimierz Wilowski, 23-34. Poznań: Wydawnictwo Naukowe Instytutu Filozofii UAM, 2003.

Bednarska, Jadwiga. Z dziejów polskiej ilustracji panegirycznej pierwszej połowy XVII wieku, cz. 1 Motywy i tematy antyczne w polskiej panegirycznej ilustracji książkowej. Studium z ikonografii sztuki nowożytnej. Katowice: Muzeum Śląskie, 1994.

Brisson, Luc. How Philosophers Save Myths. Allegorical Interpretation and Classical Mythology. Chicago: University of Chicago Press, 2004. Dostęp 20 sierpnia 2015. http:// eds.b.ebscohost.com/eds/ebookviewer/ebook/ZTAwMHh3d19fMjYwMTA2X19BTg2?sid=ca941352-d3b5-4a07-bc3f-3163f0edd041@sessionmgr113\&vid=0\&format=EB\&rid=1.

Buscaroli, Pierio. „Nota edytorska”. W Cesare Ripa, Ikonologia, XV-XX. Kraków: TAiWPN UNIVERSITAS, 1998.

Cartari, Vicenzo. Le imagini de gli Dei delli Antichi. Venetia: Appresso Euangelista Deuchino, 1625. Dostęp 15 października 2015. https://archive.org/details/leimaginideglide01cart

Collonna, Francesco. Hypnerotomachia Poliphili. Venetiis: in aedibus Aldi Mantii, 1499. Dostęp 20 lipca 2015. http://www.rarebookroom.org/Control/colhyp/index.html.

Cooper, Jaan C. Zwierzęta symboliczne i mityczne. Tłumaczenie Anna Kozłowska-Ryś, Leszek Ryś. Poznań: Rebis, 1998.

Day, David, i Ian Miller (ilustracje). Bestiariusz tolkienowski. Tłumaczenie Renata Giedrojć, Joanna Kokot, Jakub Z. Lichański. Poznań: Zysk i S-ka, 2001.

Donat, Dietrich. „Bibliographischer Beitrag”. W Filippo Picinelli, Mundus Symbolicus, 1-41. Hildesheim-New York: Georg Olms Verlag, 1979.

Drapela, Zofia. Od Lewiatana do Jormungandra: rzecz o potworach morskich, ludziach z morza i duchach wód, ilustr. Tadeusz Ciesiulewicz. Gdańsk: Wydawnictwo Morskie, 1976. 
Eco, Umberto. W poszukiwaniu języka uniwersalnego. Tłumaczenie Wojciech Soliński. Gdańsk: Marabut; Warszawa: Volumen, 2002.

Elian, Klaudiusz. O właściwościach zwierząt (wybór). Tłumaczenie, wstęp i przypisy Anna M. Komornicka. Warszawa: Prószyński i S-ka, 2005.

Evans, Edward Payson. Animal Symbolism in the Ecclesiastical Architecture: with Bibliography and Seventy-eight Illustrations, 45-91. London: W. Heinemann, 1896. Dostęp 7 listopada 2016. http://bestiary.ca/etexts/evans1896/evans\%20\%20animal\%20 symbolism\%20in\%20ecclesiastical\%20architecture.pdf.

Fizjologi i Aviarium: średniowieczne traktaty o symbolice zwierząt. Tłumaczenie i oprac. Stanisław Kobielus, Kraków: Tyniec Wydawnictwo Benedyktynów, 2005.

Gesner, Conrad. Historia animalium. T. 1-5. Zurich: C. Forschauer, 1551-1558, 1587.

Giehlow, Karl. The Humanist Interpretation of Hieroglyphs in the Allegorical Studies of the Renaissance. With a Focus on the Triumphal Arch of Maximilian I. Translated with an Introduction \& Notes by Robin Raybould. Leiden - Boston: Brill - Hes de Graaf, 2015. Dostęp 22 marca 2017. https://books.google.pl/books?id=itguBgAAQBAJ\&printsec $=$ frontcover\&hl=pl\&source $=$ gbs_ge_summary_r\&cad $=0 \# v=$ onepage \&q\&f=false

Heckscher, William S., i Karl-August Wirth. „Emblem - Emblembuch“. W Reallexikon zur deutschen Kunstgeschichte. T. 5, z. 49, 85-228. Stuttgart: Alfred Druckenmüller, 1959.

Horapollon, Hieroglify. Tłumaczenie i komentarz Jerzy Kroczek, wstęp Jacek Sokolski. Wrocław: Wydawnictwo Uniwersytetu Wrocławskiego, 2003.

Jonston, John. Historiae Naturalis de Arboribus et Plantis Libri X. T. 2. Heilbronn: F. J. Eckebrecht, 1769.

Jonstonus, Joannes. Historia Naturalis de Avibus Libri VI. Francofurti ad Moenum: impensà Matthaei Meriani, 1650.

Kircher, Athanasius. Arca Noë, in tres libros digesta, sive de rebus ante diluvium, de diluvio, et de rebus post diluvium a Noëmo gestis. Amstelodami: apud Johannem Janssonium \& Waesberge, 1675. Dostęp 7 listopada 2016. http://gallica.bnf.fr/ark:/12148/ bpt6k111864r/f102.item.zoom.

Klimkiewicz, Anna. Hypnerotomachia Poliphili Francesca Colonny. Kraków: Wydawnictwo Uniwersytetu Jagiellońskiego, 2015.

Kobielus, Stanisław. Bestiarium chrześcijańskie. Zwierzęta w symbolice i interpretacji. Starożytność i średniowiecze. Warszawa: PAX, 2002.

Krzywy, Roman. „Wstęp”. W Andrea Alciatus, Emblematum libellus: Książeczka emblematów. Tłumaczenie i komentarze pod kier. Mieczysława Mejora: Anna Dawidziuk, Bianka Dziadkiewicz, Ewa Kustroń-Zaniewska, wstęp i oprac. Roman Krzywy, III-XVIII. Warszawa: Wydział Polonistyki UW, 2002.

Kusukawa, Sachiko. "The Sources of the Gesner`s Pictures for the 'Historia animalium'”. Annales of Science 67 (2010): 303-328. Dostęp 7 października 2016. http://www. rhinoresourcecenter.com/pdf_files/128/1286404337.pdf. 
Michałowska, Teresa. Staropolska teoria genologiczna. Wrocław: Ossolineum; Warszawa: PAN, 1974.

Myśliciele, kronikarze i artyści o sztuce od starożytności do 1500, wybrał i oprac. Jan Białostocki. Warszawa: PWN, 1988.

Panofsky, Erwin. “Titians Allegory of Prudence. A Postscript”. W Erwin Panofsky, Meaning in the Visual Arts. Papers in and on Art History, 146-168, il. 28-45. New York: Doubleday\&Company, Inc., A Doubleday Anchor Books, 1955.

Paracelsus. O nimfach, sylfach, pigmejach i salamandrach, etc. Tłumaczenie Robert Urbański, wstęp i komentarz Jacek Sokolski. Wrocław: Oficyna Wydawnicza Atut - Wrocławskie Wydawnictwo Oświatowe, 2013.

Pelc, Janusz. Słowo i obraz. Na pograniczu literatury i sztuk plastycznych. Kraków: Universitas, 2002.

Picinelli, Filippo. Mundus Symbolicus in Emblematum Universitate Formatus, Explicatus, et tam sacris, quam profanis Eruditionisbus Sententiis illustratus: Subministrans Oratoribus, Praedicatoribus, Academicis, Poetis etc, innumera conceptum argumenta; Idiornate Italico conscriptus a Reverendissimo Domino, D. Philippo Picinello Mediolanensi, Canonico Regulari Lateraren. Abbate, Theologo, Lectore, Praedicatore privilegiato; Nunc verò Justo Volumine auctus et in latinum traductus à R. D. Augustino Erath, Imperialis Collegi ad B. V. in Wettenhausen; Ord. S. Augustini Canonico Regulari, SS. Theologiae Doctore ac Professore, Protonotario Apostolico ac Sub-Decono, Tomus Primus; Cum quadruplici copiosissimo Indice, Lemmatum, Applicationum, Rerum notabilium, et locorum S. Scripturae. Nunc primum in Germania prodit. Coloniae Agrippinae: Sumptibus Hermanni Demen, 1687.

Pseudo-Albert Wielki. Księga sekretów o cnotach ziót, kamieni i zwierząt niektórych, oprac. Jerzy Kroczak, Jacek Sokolski i Joanna Zagrożdżon, wstęp Jacek Sokolski. Wrocław: Oficyna Wydawnicza ATUT - Wrocławskie Wydawnictwo Oświatowe, 2014.

Ripa, Cesare. Iconologia. Roma: Appresso Lepido Faeji, 1603.

Ripa, Cesare. Ikonologia. Tłumaczenie Ireneusz Kania. Kraków: Universitas, 1998.

“Ripa, Cesare (pseudonym of Giovanni Campani)”. W Dictionary of Art Historians. Dostęp 15 października 2015. https://dictionaryofarthistorians.org/ripacf.htm.

Ronecker, Jean-Paul. Le symbolisme animal. Mythes, croyances, légendes, archétypes, folklore, imaginaire.... St.-Jean-de-Braye (France): Editions Dangles, 1994.

Rowland, Beryl. Animals with Human Souls: A Guide to Animal Symbolism. Knoxville: University of Tennessee Press, 1973.

Rowland, Beryl. Birds with Human Souls: A Guide to Bird Symbolism. Knoxville: University of Tennessee Press, 1978.

Saar-Kozłowska, Alicja. „Iustitia i religio - ‘dwa skrzydła’ wiodące duszę w sfery wyższe. Dzieło sztuki jako wzór moralno-filozoficzny na przykładzie pomnika grobowego Anny Wazówny”. W Filozofia i sztuka. Festiwal filozofii. T. 8, red. Ewa Starzyńska-Kościuszko, Andrzej Kucner i Piotr Wasyluk, 169-195. Olsztyn: Instytut Filozofii UWM, 2016. 
Saar-Kozłowska, Alicja. „Potrzeba fikcji i fantazji. Uwagi o symbolice zwierzęcej”. W Kolekcja fikcji. O mistyfikacji w sztuce, red. Małgorzata Wawrzak, 91-118. Toruń: Wydawnictwo Naukowe UMK, 2016.

Saar-Kozłowska, Alicja. „Symbolika perły. Przyczynek do badań nad wykorzystaniem motywu perły w ikonologii i emblematyce”. W Dawna i nowsza biżuteria w Polsce. Materiały z VIII sesji naukowej z cyklu „Rzemiosło artystyczne i wzornictwo w Polsce”, Gdańsk, 14-15 marca 2007, red. naukowa Katarzyna Kluczwajd, 11-43. Toruń: SHS, 2008.

Sawicka, Anna. „Średniowieczny bestiariusz kataloński na nowo odczytany”. W Bestiariusz. Tłumaczenie Rozalya Sasor, 5-23. Kraków: Księgarnia Akademicka, br. [2005].

Sokolski, Jacek. „Barokowa 'Physica curiosa' i koncepty księgi natury”. W Koncept w kulturze staropolskiej, red. Ludwik Ślęk, Adam Karpiński, Wiesław Pawlak, 297. Lublin: Towarzystwo Naukowe KUL, 2005.

Sokolski, Jacek. Słownik barokowej symboliki natury. Tom wstępny. Barokowa księga natury. Wrocław: Wydawnictwo UWr, 2000.

Sokolski, Jacek. „Wstęp”. W Horapollon, Hieroglify. Tłumaczenie i komentarz Jerzy Kroczak, 5-29. Wrocław: Wydawnictwo UWr, 2003.

Sokolski, Jacek. „Wstęp”. W Pseudo-Albert Wielki, Księga sekretów o cnotach ziót, kamieni i zwierząt niektórych, oprac. Jerzy Kroczak, Jacek Sokolski i Joanna Zagrożdżon, 5-42. Wrocław: Oficyna Wydawnicza ATUT - Wrocławskie Wydawnictwo Oświatowe, 2014.

Szrejter, Artur. Bestiariusz germański. Potwory, olbrzymy i święte zwierzęta. Gdańsk: Wydawnictwo Maszoperia Literacka; Gdańsk: Wydawnictwo Oskar, 2012.

Valeriano, Joannis Pierio. Hieroglyphica sive de sacris Aegyptiorum Aliarvmquae Gentium Literis. Coloniae Agrippinae: sumptibus Antonij \& Arnold Hierati, 1631.

Valeriano, Joannis Pierio. Hieroglyphica sive de sacris Aegyptiorum Aliarvmquae Gentium Literis. Coloniae Agrippinae: apud Joannem Wilhelmum Friessem bibliopolam, 1685.

Wittkower, Rudolf. “Hieroglyphics in the Early Renaissance”. W Rudolf Wittkower, Allegory and the Migration of Symbols, 114-128. New York: Thames and Hudson, 1987. 


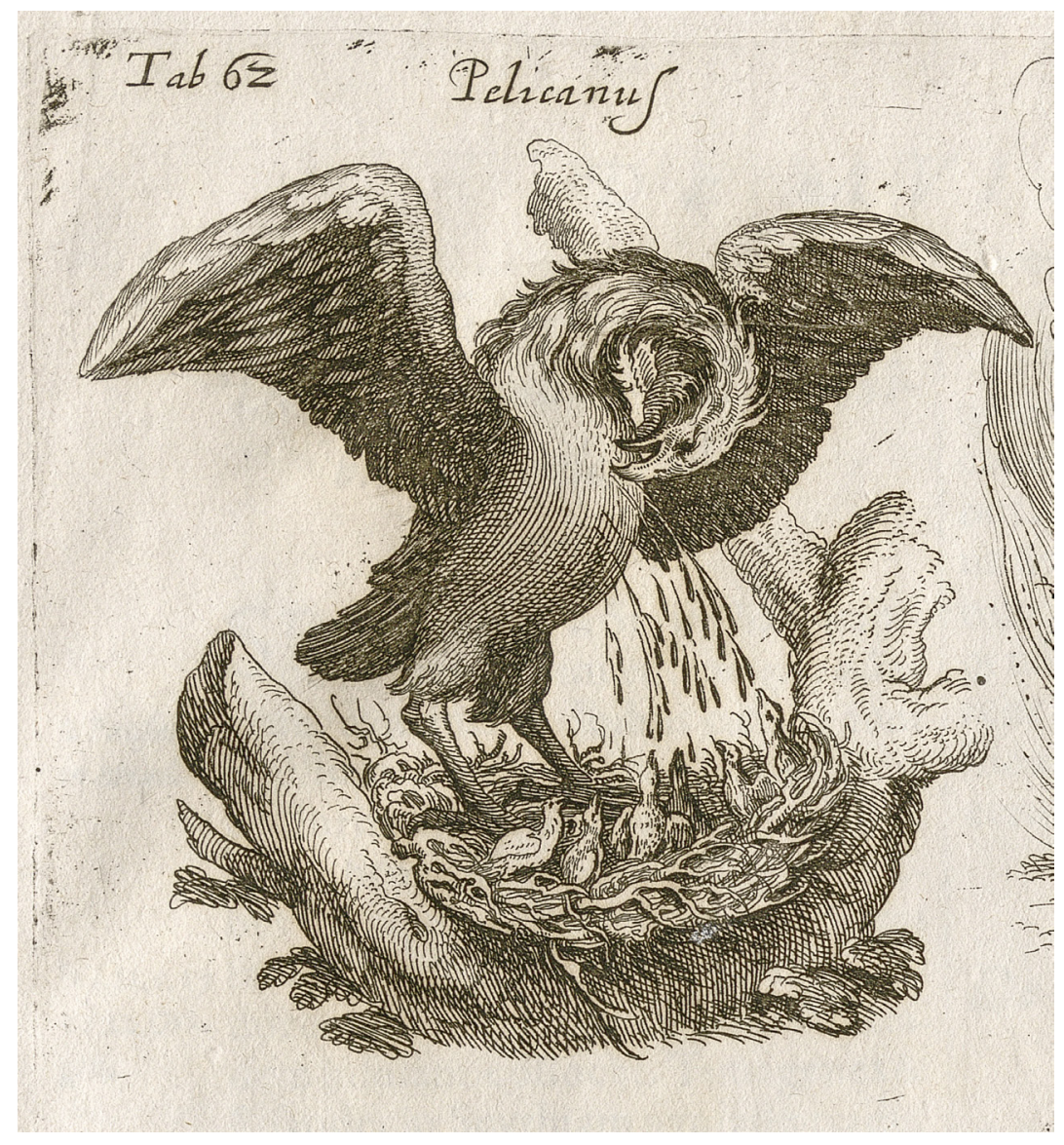

1. Feniks w: Johannes Jonston, Historia Naturalis de Avibus Libri VI, Frankfurt am Mein 1650, il. Matthäus Merian, Tab. 62 


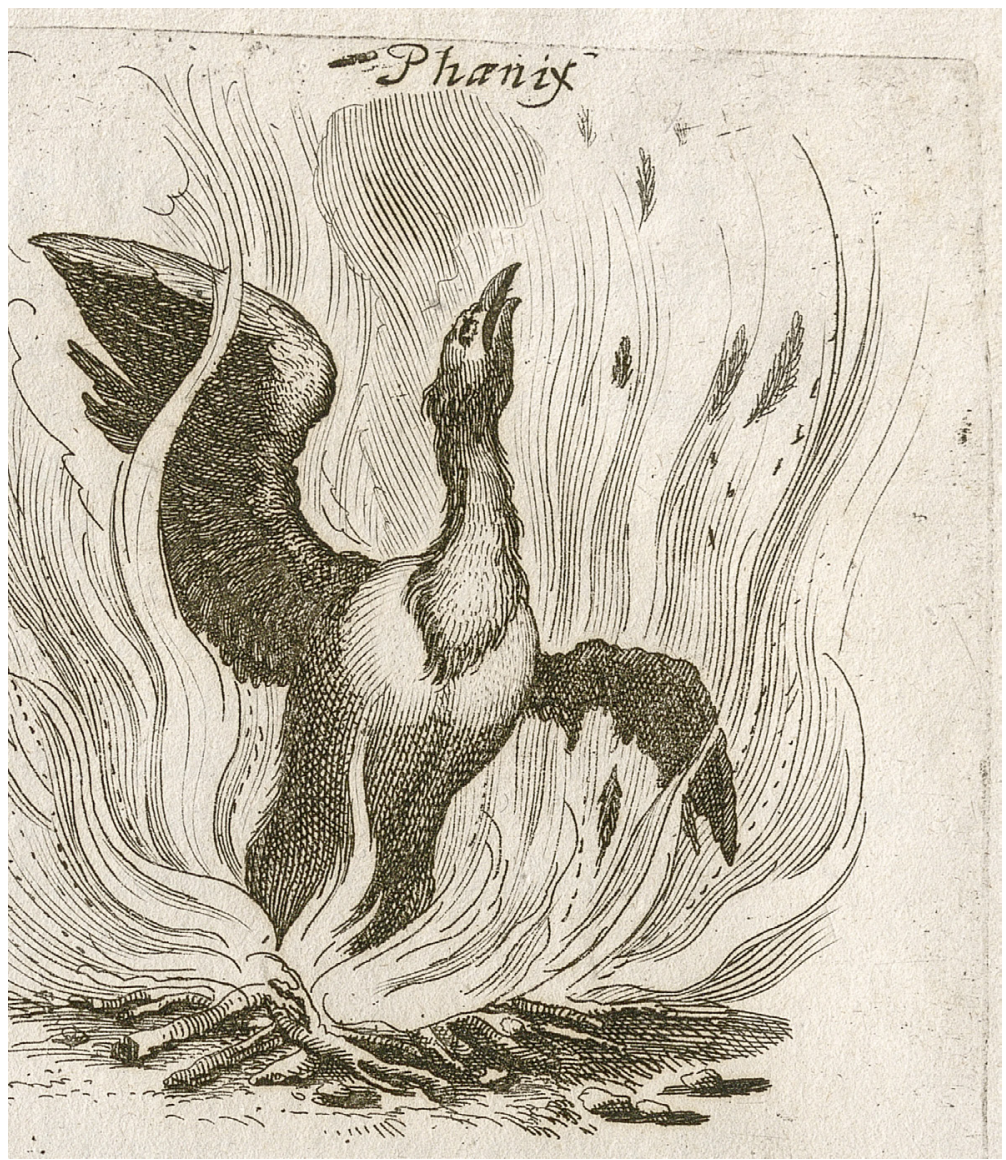

2. Pelikan w: Johannes Jonston, Historia Naturalis de Avibus Libri VI, Frankfurt am Mein 1650, il. Matthäus Merian, Tab. 62 


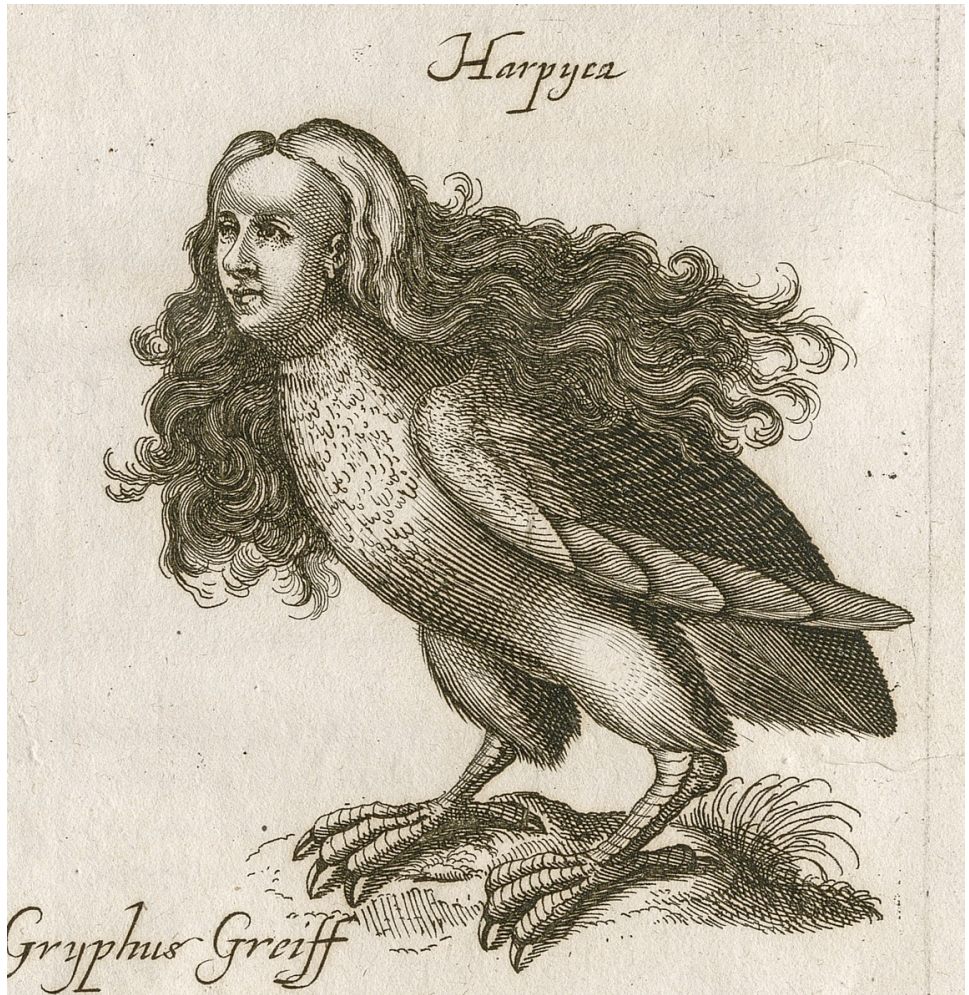

3. Harpia w: Johannes Jonston, Historia Naturalis de Avibus Libri VI, Frankfurt am Mein 1650, il. Matthäus Merian, Tab. 62 


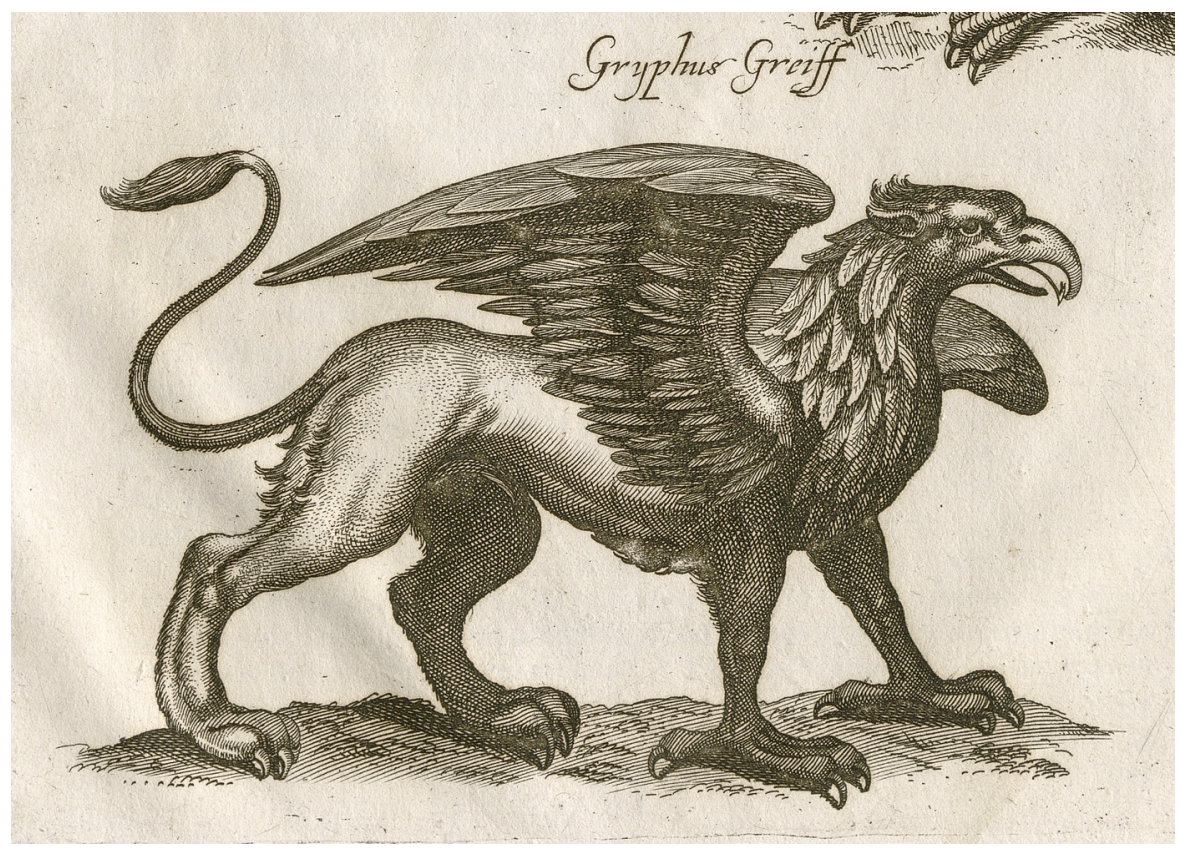

4. Gryf w: Johannes Jonston, Historia Naturalis de Avibus Libri VI, Frankfurt am Mein 1650, il. Matthäus Merian, Tab. 62 


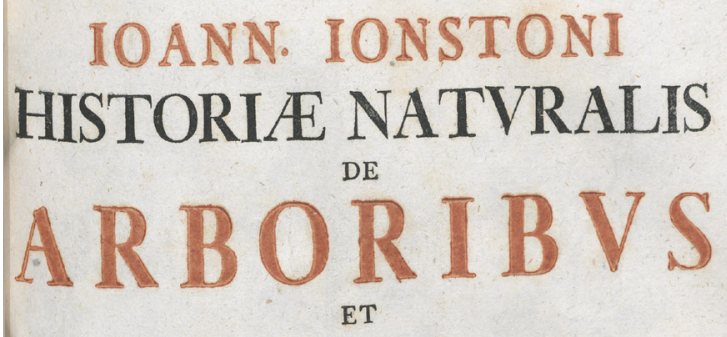

P L A N T I S

L I B R I X.

TABVLIS CENTVM TRIGINTA SEPTEM

A B ILLO CELEBERRIMO

MATHIA MERIANO

AERI INCISIS ORNATI

EX SCRIPTORIBVS TAM ANTIQVIS,

QVAM RECENTIORIBVS

MAXIMA CVRA COLLECTI,

vos

OB RARTTATEM DENVO INPRIRENDOS

S V S E P IT.

TOMVS SECVNDVS

$\Gamma A B V L A S$ CXXXVII, EXHIBENS.

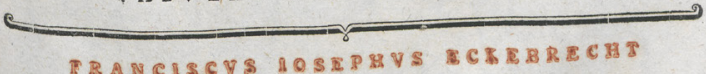

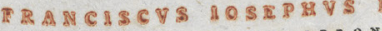

$M$ DCC LXIX

5. Strona tytułowa J. Jonston, Historiae Naturalis de Arboribus et Plantis Libri X, t. 2, Heilbronn 1769, Tab. CXXXIV 


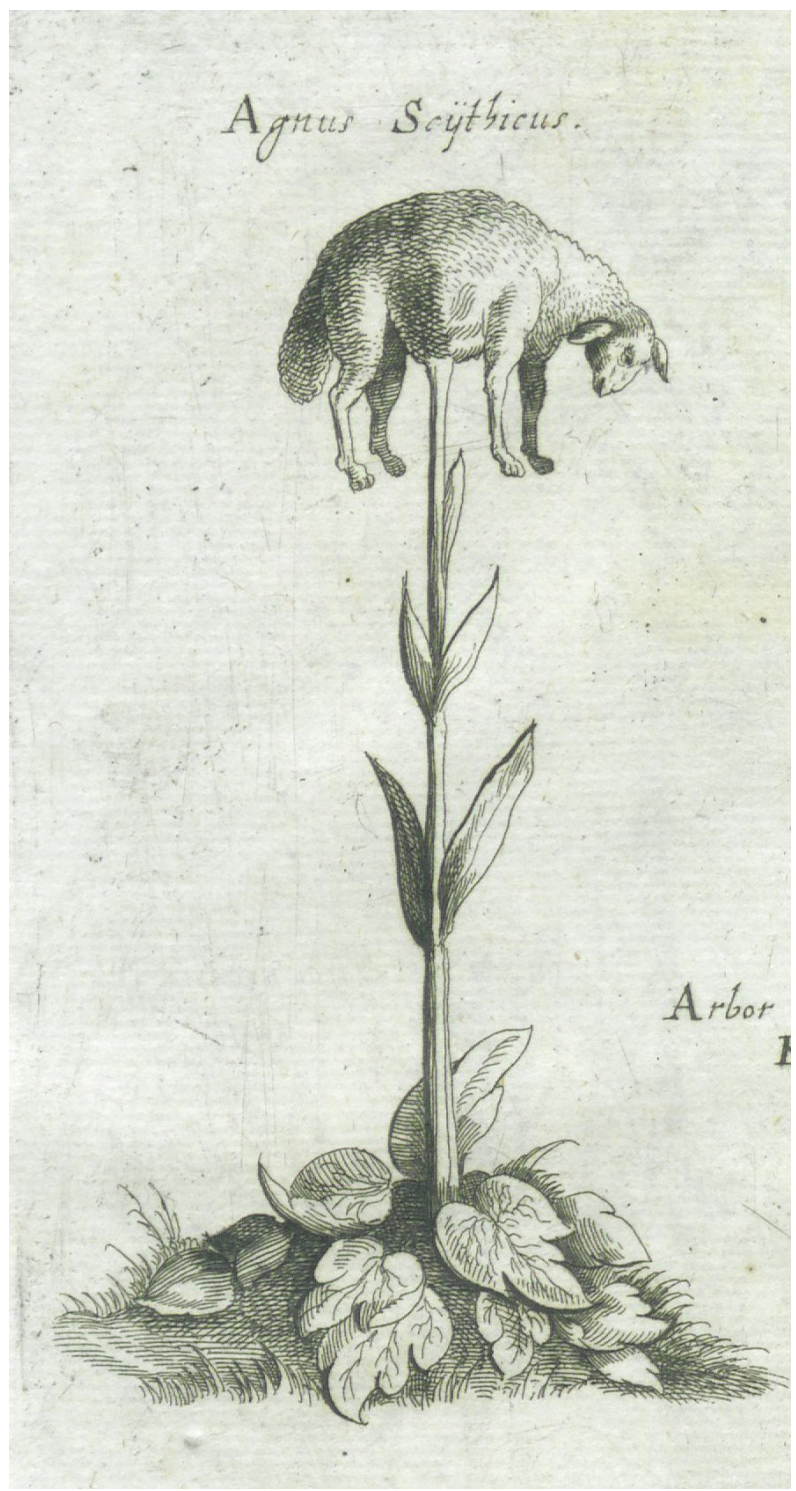

6. Agnus Scÿthicus (Baranek scytyjski) w: J. Jonston, Historiae Naturalis de Arboribus et Plantis Libri X, t. 2, Heilbronn 1769, Tab. CXXXIV 
tre
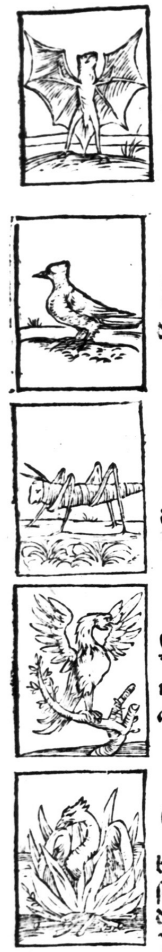

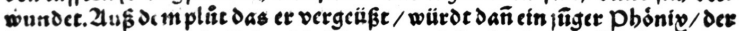
fampe dem a!cen/fo bald ime Die federn g wadben feind/gon Thebe inn dee

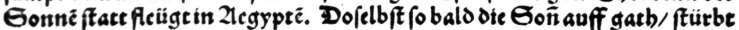

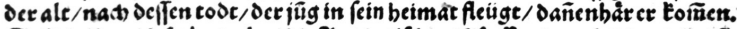

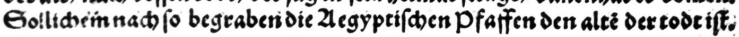

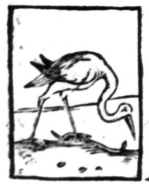
$2 \mathrm{i}$ inder liebe gegen den äleetr.

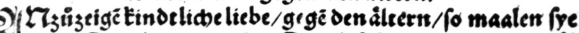
cinen Grozten/dann Der Geozd fobald er von feinen ât cern auffbzacte/faceyoter fids nummer von inze/pleybe bey

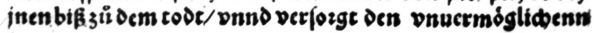
irenarung.

Staw

7. Bocian z Horapollon, Bildschrift, wg: Johann Herold, Heydenweldt.., Basilea 1552 


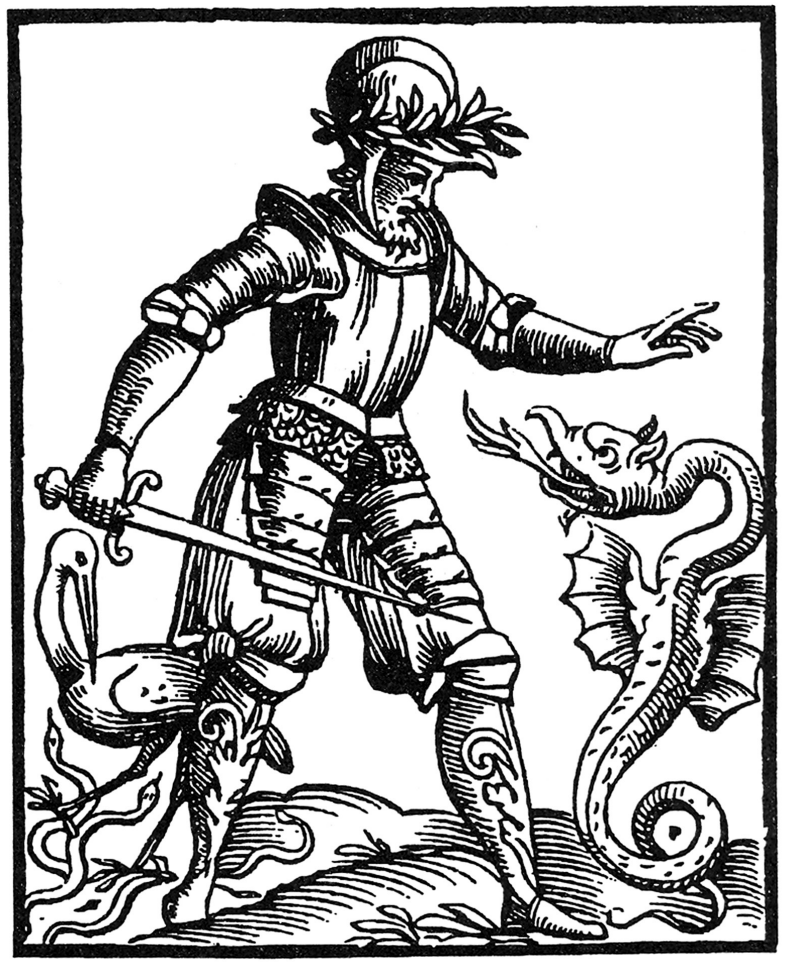

8. Pogarda i zniszczenie przyjemności tudzież złych afektów w: C. Ripa, Ikonologia, przeł. I. Kania, Kraków 1998, s. 137 

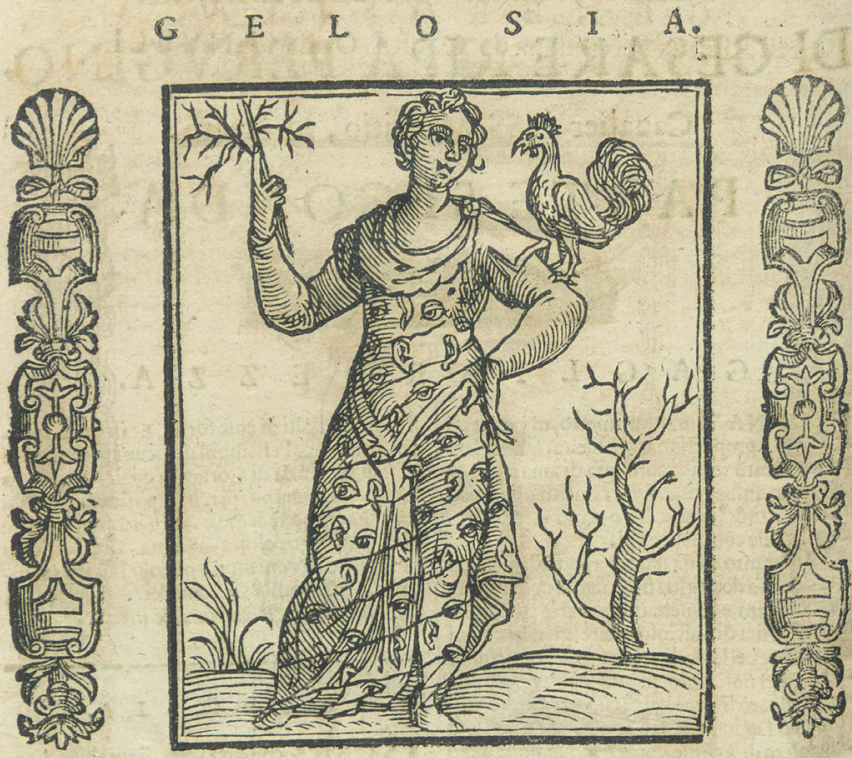

Gelo fa amante, apromill' occhi,e miro, Emill orecchi, adogni fwono intento.

II color del veft imento è proprio fionificato di Gelofia, per hauer il color del mare, il quale mainon fi moftra cosi tranquillo, chenon ne

Imazzodellefpine, dimofra if faftidij pungentiffmidel gelo!o, che di continuo lo pungono, non altrimenti, che fe foffero fpiac acutifime; 'e quali per tal cagione gli fi diping ono ir mano.

\section{Gelofia.}

Onnxveftiza nel modo fopradetto nella D deftra mano- tersà vna pianta di helilorga lóperto, cosi tra gli fcogli di Gelofia pes certo, che lhuomo fia dell'altruifedenos paffa mai lenza timore, \& faftidio.

Si fa ancora queft'inagine, che in vna matro tiene il fiore helitropio, il quale fi gira fempre intorno, eincontro al Sole, feguitanco il firo mo. to, come gelofo, co' paffi, con 'e parole, \& col penfiero, lempre ftà volto alla contemplatione delle bellezze da lui per fouerchio amoreftima cropio

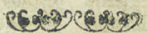

(6)

GENE:

9. Gelosia - Zazdrość w: C. Ripa, Della Piu che Novissima Iconologia, Padoua 1630, s. 286 


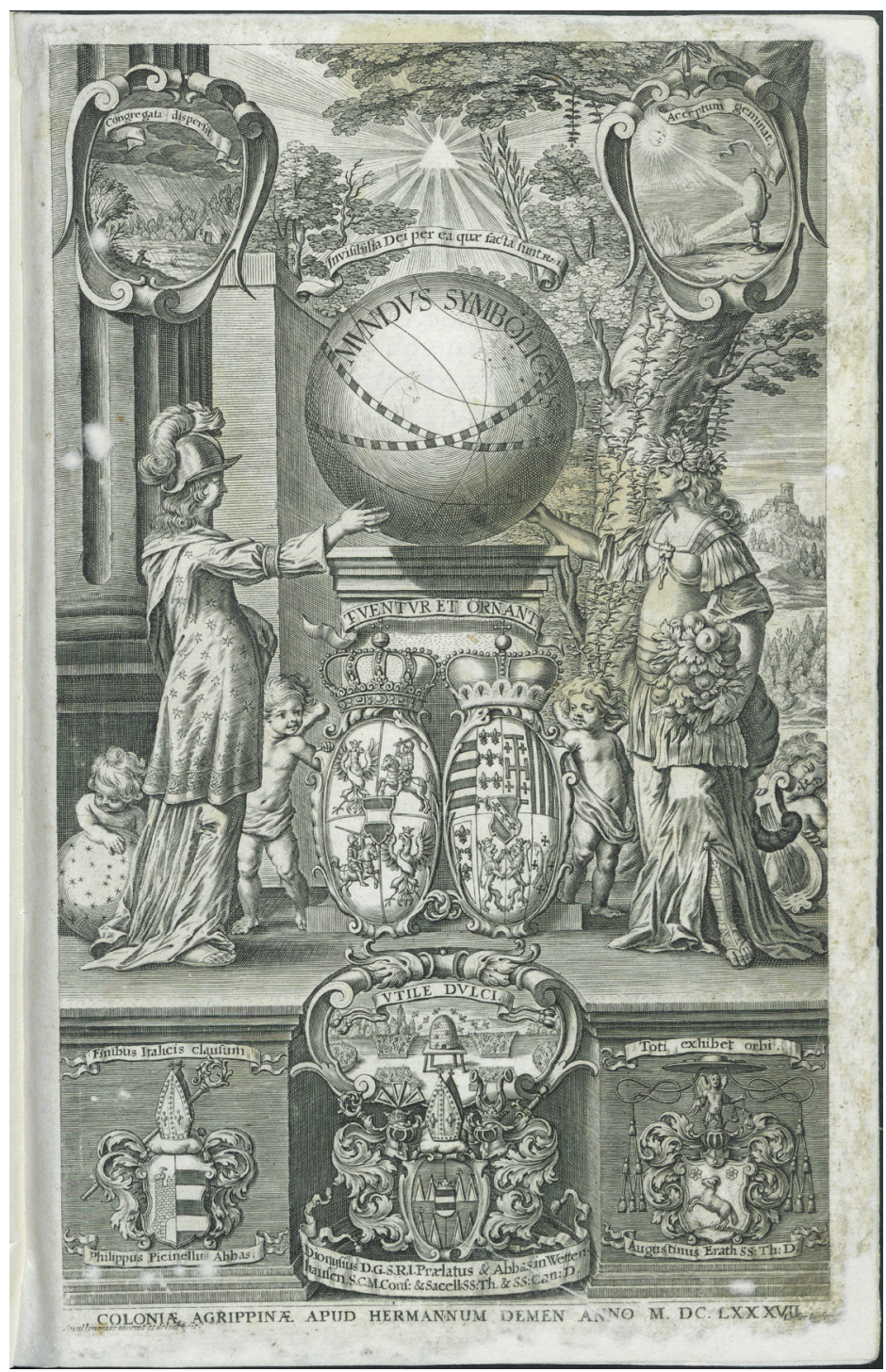

10. Strona tytułowa Filippo Picinelli, Mundus symbolicus, Coloniae Agrippinae 1687 
